UDC $791.4+008$

LBC 85.373(0) + 71.04

DOI: 10.30628/1994-9529-2021-17.2-171-213 received 30.05.2021, accepted 29.06.2021

BELLA A. BULGAROVA Peoples' Friendship University of Russia (the RUDN University), Moscow, Russia.

ResearcherID: G-3631-2016 ORCID: 0000-0001-6005-2505 e-mail: bulgarova-ba@rudn.ru

ALEXEY YU. OVCHARENKO

Peoples' Friendship University of Russia (the RUDN University), Moscow, Russia

ResearcherID: Z-3696-2019

ORCID: 0000-0002-8544-5812 e-mail: ovcharenko_ayu@pfur.ru

VICTOR V. BARABASH

Peoples' Friendship University of Russia (the RUDN University), Moscow, Russia ResearcherID: P-6349-2017 ORCID: 0000-0002-8909-2145 e-mail: barabash-vv@rudn.ru

JULIA A. VOROPAEVA

Peoples' Friendship University of Russia (the RUDN University), Moscow. Russia ResearcherID: AAN-5202-2020 ORCID: 0000-0002-5425-3359 e-mail:voropaeva_yua@pfur.ru 


\title{
"EVERY GENERATION HAS ITS SHERLOCK": THE CHARACTER'S IMAGE IN THE FILM ADAPTATIONS OF STORIES BY A. CONAN DOYLE ABOUT SHERLOCK HOLMES ${ }^{1}$
}

\begin{abstract}
The article covers the problem of the protagonist's image portrayal in modern cinema on the example of the three most recent film adaptations based on works by Conan Doyle. The relevance of this scientific issue is explained by the fact that the peculiarities of representing the character in modern cinema partly reflect the state of society itself, its social problems, phobias and neuroses. Cinematography, like no other type of contemporary art, has broad opportunities to embody almost any character in three-dimensional reality, which imposes a certain social responsibility for the results of the main characters' portrayal. The appeal to the archetypal images of world literature implies not only the openness of improvisation, but also the preservation of the character's social function. The article analyzes the representation of one of such archetypal images of world significance-Sherlock Holmes. The research methodology is based on a systematic approach and general scientific methods, and also includes special methods: content analysis of scientific literature related to the topic; the method of sociological survey (questionnaire survey), the method of statistical analysis. The empirical study, the results of which are presented in this article, is based on three screen adaptations of the Sherlock Holmes stories, produced in the 2000s in Great Britain, Russia and the United States. The study involved 150 respondents, whose answers were converted from a qualitative to a quantitative format to analyze the specifics of the representation of the main character (the protagonist). The authors of the article came to the following conclusions: in modern film adaptations the protagonist is portrayed not as a genius of the scientific method of thinking, but as a sociopath who is unable to interact with society without an intermediary (a companion character). Moreover, modern screen adaptations violate the archetypal image itself due to improvisations with the static characteristics of the character, which leads to a negative perception of such a character by the audience. The very strengthening of sociopathic features of the protagonist's character, shifting the emphasis from the idea of higher justice, from eternal values to private motives, lead to a certain simplification
\end{abstract}

\footnotetext{
${ }^{1}$ Authors are deeply grateful to the translators: Diana S. Solobuto, Senior Lecturer at the Maurice Thorez Institute of Foreign Languages, Member of the Union of Writers of Russia, Winner of the Golden Pen of Russia Award-2007 (Moscow, Russia), and Irina B. Maslova, Head of the Department of Russian as a Foreign Language at the Institute of International Educational Programs (Moscow, Russia).
} 
of the character, and also serve as an indicator of the state of society itself. The theoretical significance of the research is determined by the fact that this article offers original criteria developed by the authors to analyze the representation of the character. The practical significance of the article is backed by the conclusions and results of the study, which can be used for further work to identify the impact of characters' representations on shaping value orientations in modern society.

Keywords: cinema, protagonist, character, improvisation, static characteristics of the character, dynamic characteristics of the character, social function, archetypal image, ways of representation

\section{INTRODUCTION}

The relevance of the topic is due to the fact that the problem of representing the main character (the protagonist) is an indicator of aesthetic, moral, ethical and mental characteristics of modern society. Modern cinema, undoubtedly, possesses the most powerful tools for this purpose, being a part of the general screen culture [1], allowing to transmit the created images to the whole world, to replicate and visualize fictional and national-political myths $[2$, p. 119]. The popularity and wide coverage of the cinema, its modern digital versions and a wide range of expressive means determine the uniqueness and special power of the impact this type of art has on the modern world.

Movie makers use certain techniques to build and develop characters. The choice of filming techniques, action, mise-en-scene, editing, lighting and sound-all of it determines the artistic way of shaping the character's image using a combination of the author's thought and cinematic techniques. The process of transforming an artistic image into a screen image is based on a specific cinematographic dramaturgical canon. Both mise-en-scene-colors and light, costumes, makeup, placing of props, placement of actors on the set-and the shot composition itself carry certain information about the character, which was already pointed out by S.M. Eisenstein [3, pp. 81-93] and L.V. Kuleshov [4, pp. 75-95] in the 1920s-1930s. Cinematographers carefully consider the frame sequence, the montage tempo and the usage of editing techniques, which also influence the narration, the character's representation and the involvement of the audience into the action. Coincidental sound trimming, continuity editing, frame cutting, insertion, dissolving, gradual appearance, disappearance, rapid movement, transition, overlappingthese all are editing techniques that also contribute to the character's image $[5$, p. 50]. In most feature films, although the lighting may look usual and 
natural, the filmmakers put a lot of effort to achieve the specific effect they want. Lighting always significantly and meaningfully contributes to the narrative-German expressionism and film noir, with their semidarkness, interplay of shadows and side-lighting of characters' faces, are classical examples. Filmmakers carefully consider the quality and location of light sources, influencing the narrative and character development [6, p. 130].

The sound sequences in the motion picture are also carefully thought through, the same way the visual editing of the film is. Sound effects and music also contribute significantly to the creation of the screen image. According to most researchers of modern cinematography, the representation of the character in the film can also be described by the formula: "dialogue + physical movement $=$ the character" [7, p. 2].

This brings us to the main component of the film-its characters. Identifying oneself with the characters is a frequent reason why people are attracted to a particular film. Viewers want the protagonist and supporting characters to evolve just like people in real life do. They want a film to reflect this evolution; the character must show the development of moral and ethical virtues, such as decency, honesty, or courage, and "have a very detailed biography, which makes the character three-dimensional" [5, p. 54].

To create a three-dimensional character with a well-developed background, a film must illustrate the sociology, psychology, and physiology of the character. Since a film is a visual experience, sociology and psychology, together with physiology, are subtly portrayed using visual means through physical movements and dialogues in any situation depicted in the film.

By shaping the character in cinematography, his or her physical actions and dialogues change depending on the exposition and conflict, as he or she is moving through the rising and falling action of the film. Each frame should be aimed at completing the action and developing the character's story. Besides, dialogues in these situations should match physical movements. For example, dialogue "cannot be ranting and raving about a particular situation when a character is standing still, looking into the window" [8, p. 102].

In the history of cinema there have been many examples of representing a character from literature. But for now, Sherlock Holmes, striking as it may seem, remains the most brilliant and popular image to be portrayed on the screen, a character created two centuries ago and still successfully gaining the attention of viewers. This character, according to K. Jung's famous ideas, is an archetypical image carrying a social idea in itself, the idea that has been 
significant for the whole mankind in the course of all periods of historical development, clear for any national culture and complying with the moral and ethical demands of the society [9, p. 9]. In the case of Sherlock Holmes, an archetype that appeared in the late 19th-the first half of the 20th century reflects the idea of higher justice, which can be implemented by man with the help of scientific analysis.

Analyzing this timeless image, some researchers note that "Sherlock Holmes is one of the most adapted characters of all times" [8, p. 17]. The phenomenon of this character lies in the fact that it represents not only an archetypal image, clear and accessible for any culture and nation, but also that it actually reflects the myth of Holmes, which has absorbed the intertextuality of the previous screen incarnations, a kind of "Holmes's canon". In scientific literature, there have been many attempts to analyze the phenomenon of this character, from studying the discrete transition of the text from page to the screen $[8, p .18]$ to the character's evolution as it has been changing in various intertexts and through time [10, p. 226]. By analyzing, researchers tried to show that it is the character that is adapted, not the fictional text with its narrative, genre and aesthetic aspects, and thus, studying screen representations of Sherlock Holmes should include analysis of various aspects related to cinematography that shape, change and define this character throughout his hundreds of screen lives. To date, the world cinema has 135 cinematic incarnations of Sherlock Holmes, created by actors from different countries (UK, Russia, USA, Canada, Poland, Japan, etc.) [11, p. 44] (Fig. 1, p. 174).

The study of Sherlock Holmes's archetypal image in the context of its cinematographic representations allows, in our opinion, to identify the main peculiarities of modern interpretations of the character and to reveal the specific attitude of modern society to the character. There are different points of view on the specifics of the screen image embodiment. For example, in his work A. Bachmann puts forward the following thesis: "Countless reinterpretations have touched all the aspects of Holmes's character and world-costume, appearance, time period, gender, sexuality-but one thing never changes: he is a scientist. This character is a mixture of all the stereotypes we have ever had about scientists-lonely, introverted, brave, reckless, a little inhuman, cruel, obsessive, creative, and brilliant" [10, p. 329].

This statement can be taken as a ground for analyzing the peculiarities of the character's representation, since the world in which he was originally created was literally obsessed with science. The Victorian era saw the creation 
of Charles Babbage's first "Analytical Engine", a precursor of modern computer technology. Many literary predecessors of Holmes, detective charactersA. Dupin by Edgar A. Poe, Lecoq by Emile Gaboriot, "The Thinking Machine"Professor Van Dusen by Jacques Futrelle-were characters who were proud of their systematic, unemotional approach to solving complex mysteries $[13$, p. 38$]$

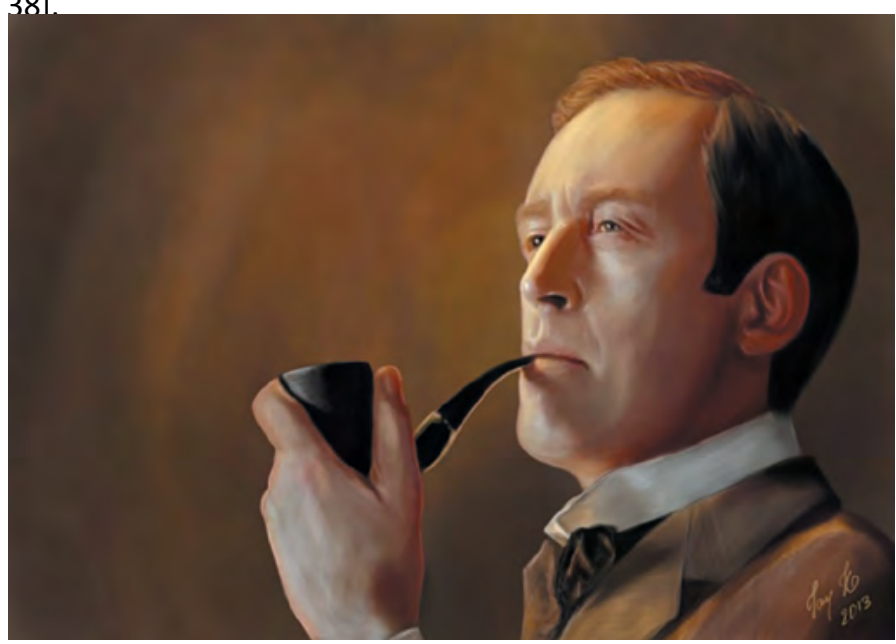

Fig. 1. The canonical image of Soviet cinema-Sherlock Holmes performed by V.B. Livanov. Screen capture from the series of television films The Adventures of Sherlock Holmes and Dr. Watson directed by Igor Maslennikov, 1979-1986²

Sir A. Conan Doyle's character, Sherlock Holmes in his classic version was also distinguished by his lack of emotion. (Interestingly, in British detective fiction there is also an exact opposite of Holmes-H.C. Chesterton's Father Brown, who relies not on logic to investigate crimes, but rather on his knowledge of human nature. Robert Hamer's 1954 adaptation of The Blue Cross-Father Brown, starring Alec Guinness, is considered a reference standard. Comparing cinematic representations of Father Brown, including the one in BBC One series Father Brown (2013-2020) and cinematic representations of Holmes is a topic for further research) (Fig. 2).

\footnotetext{
$2 \overline{\text { See the image source: }}$ https://aif.ru/culture/movie/1076684 (08.07.2021).
} 


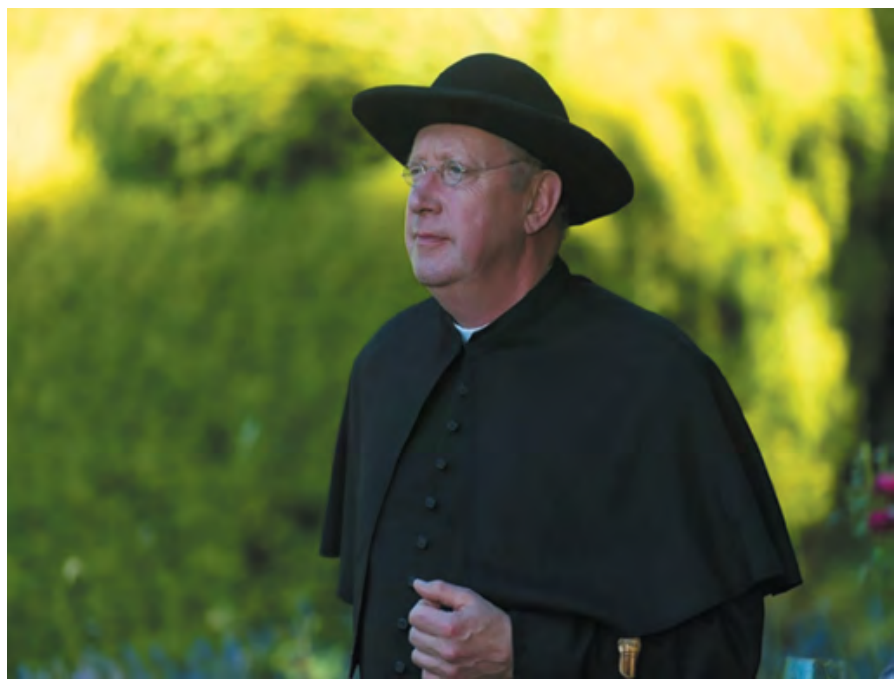

Fig. 2. Father Brown performed by Mark Williams.

Screen capture from the BBC One series Father Brown (2013-2020).

The series is based on the works of Gilbert Keith Chesterton about the Catholic priest-detective father Brown ${ }^{3}$

As with Babbage's machine, it is not the personality that is involved here, but only the application of the method. But apparently, as A. Conan Doyle well knew, no scientist, let alone a popular character from literature, can survive only thanks to cold mechanical logic [13, p. 39]. A stubborn collector of facts, devoid of imagination, is not our only stereotypical image of a scientist. Holmes is also a reserved eccentric man relying on intuition and mysterious flashes of insight. In some cases, he completely "abandons his deductive methods and chooses good old-fashioned fist-fighting" [13, p. 40]. By combining these seemingly contradictory characteristics, Holmes becomes a more realistic scientist and person than any of his fictional rivals. He also adapts himself well-each film director creates his own image of Holmes, guided by a canonical set of personality traits attributed to this figure from literature. As N. McCaw writes: "Some emphasize drug abuse in this character, others emphasize playing the violin, and others emphasize wit. P. Downey Jr. focuses on his physical shape, Jeremy Brett was quietly mysterious, Basil Rathbone

${ }^{3}$ See the image source: https://www.kino-teatr.ru/kino/movie/euro/117224/foto/864506 (08.07.2021). 
was a classic gentleman, and Cumberbatch's Holmes is a brilliant intellectual. But they are all scientists because the method and purpose never change" $[13$, p. 46]. A. Conan Doyle's character, thus, has no clear, closed characteristics, which gives almost boundless freedom for interpretation, representing a kind of cinematic palimpsest.

This aspect, perhaps, is at the heart of this appeal of Holmes as a character in modern cinema, especially in its neo-Victorian version, which also has a therapeutic effect: the viewer is comforted by the idea that, however mysterious the riddle may be, there is a solution that someone can find and will surely find, that Holmes uses logic, imagination and help of volunteersstreet boys, rather than relying on artificial intelligence to solve problems. In his review of Guy Ritchie's film A. Anastasiev, however, emphasizes that the film reflects the public mood and demands of mass culture of the 2000s for anti-science and all kinds of mysticism [12].

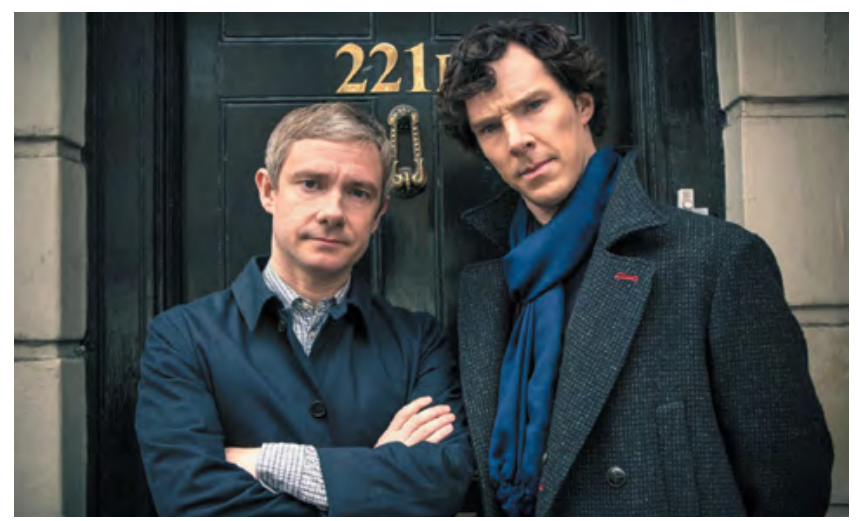

Fig. 3. Sherlock Holmes performed by Benedict Timothy Carlton Cumberbatch. Screen capture from the British television series Hartswood Films, shot for BBC Wales. The plot is based on the works of Sir Arthur Conan Doyle about detective Sherlock Holmes, but the action takes place (with the exception of one series) nowadays (2010-2017) ${ }^{4}$

However, in the three most recent film adaptations Sherlock starring B. Cumberbatch (2010-2017) (Fig. 3), Sherlock Holmes (2009) and Sherlock Holmes: A Game of Shadows starring R. Downey Jr. (2011) (Fig. 4) and Sherlock Holmes starring I. Petrenko (2013) (Fig. 5) the love of viewers to Holmes as well as to science is clouded by concerns: it is not very clear from the representation

\footnotetext{
4 See the image source: sherlock-serial-sherlock-bbc-sherlock-holmes-sherlock-she-39.jpg (1332×850) (goodfon.ru) (08.07.2021).
} 


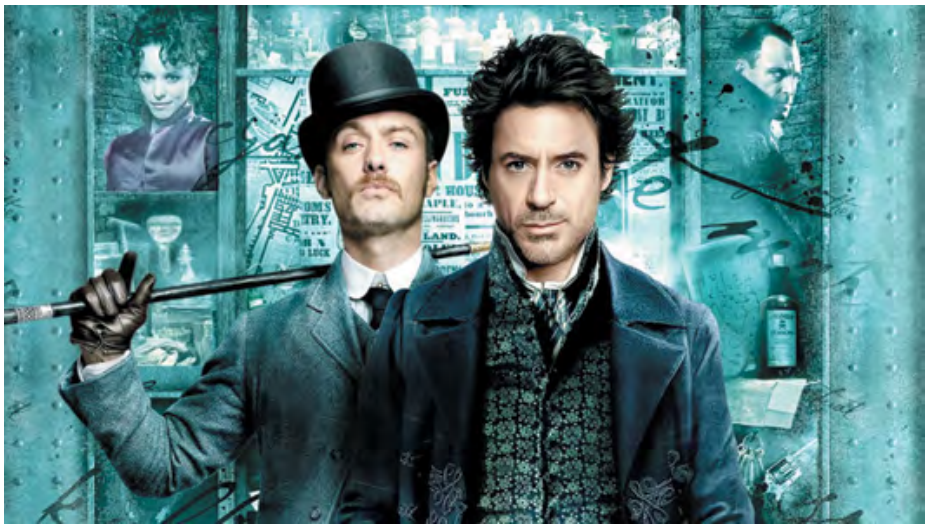

Fig. 4. Sherlock Holmes performed by Robert John Downey Jr.

Screen capture from the American film Sherlock Holmes is a detective action film directed by Guy Ritchie, which is based on the works of Arthur Conan Doyle about Sherlock Holmes, although the main plot is original.

The film premiered on December 24 (in Russia-December 31), $2009^{5}$

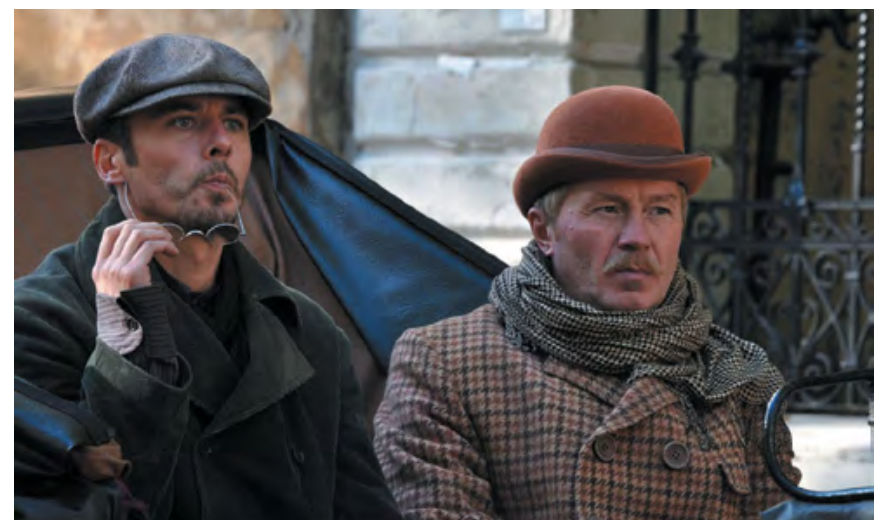

Fig. 5. Sherlock Holmes performed by Russian actor Igor Petrenko.

Screen capture from the Russian television series produced by the Central Partnership film company, shot by director Andrei Kavun based on the stories of Arthur Conan Doyle about detective Sherlock Holms.

The film premiered from November 18 to 28,2013 on the TV channel Russia- ${ }^{6}$

of this character in these films, how far he can go in his search for truth. If we take into consideration that Sherlock Holmes's archetype is expressed

\footnotetext{
${ }^{5}$ See the image source: https://thumbs.dfs.ivi.ru/storage28/contents/9/8/28252fd2c21f9ed090 83fa0f8fb086.jpg (08.07.2021).

${ }^{6}$ See the image source: https://rg.ru/2013/12/31/holms-site.html (08.07.2021).
} 
not only in the universal cultural idea of the eternal triumph of justice, but was perceived throughout almost the whole 20th century as a source of the rational and the scientific [11, pp. 65-66], then it is important to determine, how exactly the representation of this character is shaped in modern cinema, how modern audience sees the character and, accordingly, how modern society perceives higher justice and whether it needs it.

Scientific literature on the problems of film adaptations is quite extensive, has a long tradition, and includes works of both Russian and foreign authors. Theoretical foundations of the interrelation between literature and cinema were laid by Russian formalists Yu.N. Tynyanov [14, pp. 55-85], V.B. Shklovskij [15, pp. 709-871], S.M. Eisenstein [16, pp. 283-297] and L.V. Kuleshov [17, pp. 99-112], which were close to the circle of the mentioned ones, and others. These ideas were further developed in the later works by Y.M. Lotman $[18$, P. 38-46].

The works by Russian scientists V.A. Kolotaev, A.V. Markov [6], O.Yu. Osmukhina [19], T.V. Savelyeva [20], E.N. Shapinskaya [7, 21], O.I. Yushchenko, Y.A. Gamaleeva [2], A.N. Yankovsky [5] are dedicated to a more specific problem-character representation in cinematography.

Foreign researchers who study film adaptations of works of literature, starting with S. Kracauer's book Nature of Film: The Redemption of Physical Reality (1960), have analyzed both general theoretical problems of the relations between literature and film: $\mathrm{S}$. Kracauer writes about cinematographic nature of literary works and about limited abilities of cinematic language in preserving the spirit of literary source [22, pp. 313, 316]; and more specific issues: for instance, Bryan McFarlane writes about two different languages - the language of literary sources and the language of the film director to narrate the same story, distinguishing between "stories told" (the plot of the source) and "stories presented" (the cinematic interpretation). Most works, however, concentrate on how characters are represented on the screen. The works of such authors as L. Benett, D. Hwang [11], A. Bachmann [10], N. McCau [13], C. Naidoo [9] and A.L. Polachek [8] offer the authors' original techniques for analyzing cinematic representations of characters based on empirical research. Nevertheless, modern scientific literature has not yet analyzed the criteria for evaluating the representation of characters and its perception by viewers. From this point of view, the study presented in the article has a certain scientific novelty and contributes to the Russian scientific literature on the topic under study. 


\section{METHODS}

The research methodology is based on systematic approach, including general scientific methods (analysis, synthesis, deduction, induction), as well as a number of specified methods: content analysis of scientific literature on the topic; method of sociological research (method of mechanical sampling and questioning) and method of statistical data analysis.

Content analysis of the scientific literature on the topic allowed us to identify two criteria for evaluating the representation of the character:

1. Static (unchanging) basic characteristics: the character's background, appearance and attributes (cap, pipe, raincoat, violin) ${ }^{7}$, the protagonist's companion (J. Watson). Despite the fact that in the series Elementary (20122018) the character of Watson is represented by a woman, as an exception to the classic set of static characteristics of the archetype, the companion of the character is always present as a constant value.

2. Dynamic characteristics: the character's habits, manifestations of his temper, moral and ethical beliefs. These characteristics may change in the socio-historical context of almost a century-long history of film adaptations about Sherlock. Moreover, all of the later versions present the character almost as an open sociopath (Sherlock by Igor Petrenko is the most graphic example).

We conducted a mini-survey in the social network Twitter in the group "Contemporary Cinema" in order to assess the specifics of the character's representation. The questionnaire contained six questions (three questions for each criterion of representation that we've singled out).

\section{MATERIALS OF THE STUDY}

We selected three most recent film adaptations as the object of our study (Sherlock in Russia, 2020, directed by Nurbek Egen, is not a screen version in its full meaning; the series was based on an original script offering a free interpretation of the classic image of Sherlock Holmes.), what Ilona Egiazarova writes about in her review [24], placed in chronological order in the survey: Sherlock Holmes by Guy Ritchie (2009, USA); Sherlock by Mark Gatiss (2011-2016, UK) and Sherlock Holmes by Andrey Kavun (2013, Russia). The criterion for the analysis of the received responses is a 10-point level

\footnotetext{
${ }^{7}$ Sidney Paget created an iconic image of Sherlock and Watson on the pages of The Strand Magazine in 1891 illustrating the story Scandal in Bohemia. It is this image that guided the creators of many films and TV series about the famous detective: these drawings were used by Igor Maslennikov when he was selecting the cast for his TV series The Adventures of Sherlock Holmes and Doctor Watson (1979-1986).
} 
system that evaluates the perception of the character's representation in each of the film adaptations: 1-3 points-low level, 4-6-medium level, 7-10high level. All the results obtained were summarized; the average for each of the questionnaires, and then the average for each of the screen adaptations assessed by the respondents was calculated. Such a system made it possible to convert qualitative results (the respondents' answers) into quantitative data, which were then processed using special Neural Designer software applied for advanced statistical analytics.

The questionnaire designed for the mini-survey included the following questions:

1. Evaluate to which extent the image of Sherlock Holmes matches the idea of higher justice.

2. Evaluate to which extent the character's appearance reflects his character traits.

3. Evaluate to which extent the character's genius is expressed in this adaptation.

4. Evaluate to which extent the character's sociopathy is expressed in this adaptation.

5. Evaluate how dangerous this character might be.

6 . Evaluate how reliable such a character might be as an embodiment of the idea of justice.

The presented questions allowed us to reveal the viewers' attitude to the character, as well as to find out the main trend in the cinematographic representations of Sherlock Holmes at the present stage of development of this image.

A total of 150 respondents took part in our mini-survey. The survey was conducted in two languages (Russian and English), which allowed us to involve a broad audience. The research was conducted in the period from May 1 to May 20, 2021.

\section{RESULTS}

The conducted survey gave the following results: according to the film adaptation by Guy Ritchie, $90 \%$ of the respondents estimated the character as an unreliable, too emotional, unbalanced person, who is not able to play a meaningful role in achieving higher justice without his companion. Among the respondents' answers there were, for example, the following remarks: "he's always drunk, I don't like it, how can you investigate something if you just can't stand on your feet", "it seems to me, if it wasn't for Watson, such a Sherlock 
would have been killed several times in London even in broad daylight"; "Downey Jr. has a way of being a hero, but he's no closer to Holmes", etc. Statistical data of the survey results are shown in the Fig. 6.

Screen adaptation by Guy Ritche

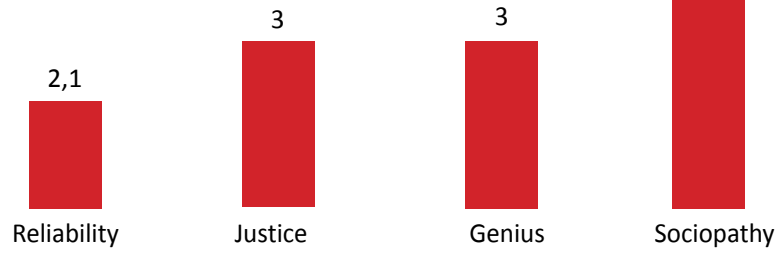

Fig. 6 . The representation of the character in the adaptation by Guy Ritchie

As you can see from the data in the Fig. 6, in the representation of the character in Guy Ritchie's film, sociopathy comes to the fore: justice, reliability and genius are evaluated by the viewer at a low level.

The screen version by Mark Gatiss had the following results: $75 \%$ of respondents rated Sherlock as a sociopath, $15 \%$ as a genius and the embodiment of higher justice. At the same time the following statements were mentioned in the respondents' answers: "I like this Sherlock, he is a kind of extraordinary", "he looks more like a genius than a drunkard, like it was with Guy Ritchie", "Cumberbatch is not appropriate for the role of classical Holmes, but the actor completely expressed what the director wanted to express". The work of cameramen, the soundtrack, and high-quality work of script-writers played their role in representation of the character: "the script is brilliant, without it Cumberbatch's Holmes would be very boring", "the cameraman's work is excellent, the camera saved Cumberbatch from a failure". It is interesting that the respondents especially mentioned the technical ways of representing the character. Also $85 \%$ pointed out that "Holmes exists only thanks to Watson", "I like the character more than Holmes", "Watson is more natural than Sherlock". The second film adaptation we analyzed, thus, allowed us to reveal the role of technical means in the representation of the hero, as well as the shift of the emphasis from the protagonist to his companion.

The results of the survey related to the second film adaptation are presented in the Fig. 7. 


\section{Screen adaptation by Mark Gatiss}

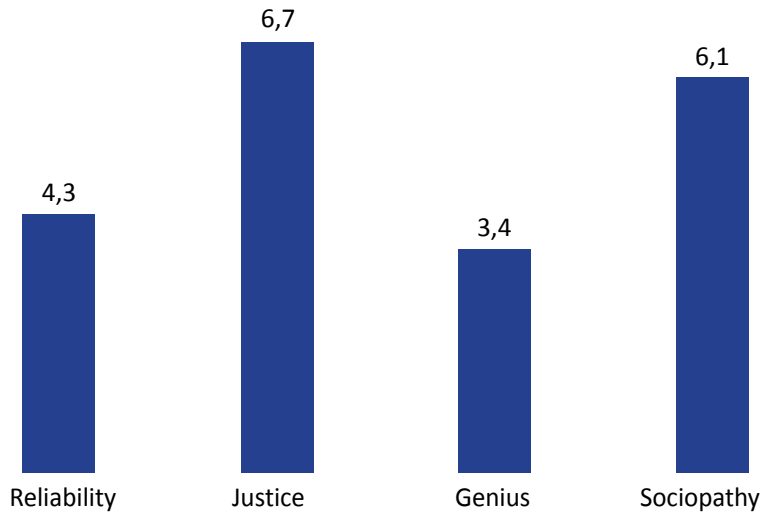

Fig. 7. The representation of the character in the adaptation by Mark Gatiss

As you can see from the data presented in the Fig. 8, the main characteristics of the character's representation in Mark Gatiss' adaptation were sociopathy and the idea of justice, while the reliability of the hero was rated at an average level and his genius earned a low rating.

Concerning Andrey Kavun's film adaptation, the following data were obtained: $89 \%$ of respondents rated Holmes as unreliable, unbalanced, neurotic, actually a sociopath, with almost no signs of genius. At the same time the following opinions were expressed: "he is running like a person stung by a wasp throughout the film, his hands are shaking, he's all twitchy and insecure", "how a man who cannot cope with his own emotions, can investigate something", "Holmes looks like a mental patient", "he is puffing all the time and uttering words through his teeth, he's weird" (see the Fig. 8).

The summary chart of the data on the three film adaptations (fig. 9) shows an increase in sociopathy in the representation of the hero.

Let us point out that in this screen version the image of the character's companion was liked by everyone as an antipode to the presented Holmes: "Watson is always concentrated, clever, fair and human, he is better than Holmes", "without Watson such a Holmes is something unreal, he would have died of his hysterics before his time". Such opinions show that the representation of the protagonist through the supporting character-his companion-led to the opposite effect: the audience doesn't perceive the protagonist as the main character, and the supporting character takes the central place. 


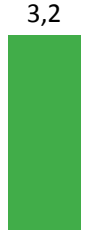

Reliability

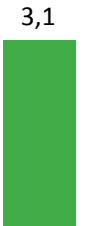

Justice
3,2

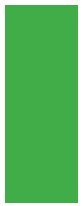

Genius

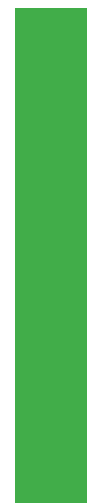

Sociopathy

Fig. 8. The representation of the character in the adaptation by Andrey Kavun

The summary chart of the data on the three film adaptations (fig. 9) shows an increase in sociopathy in the representation of the hero:

Summary data of three film's adaptation

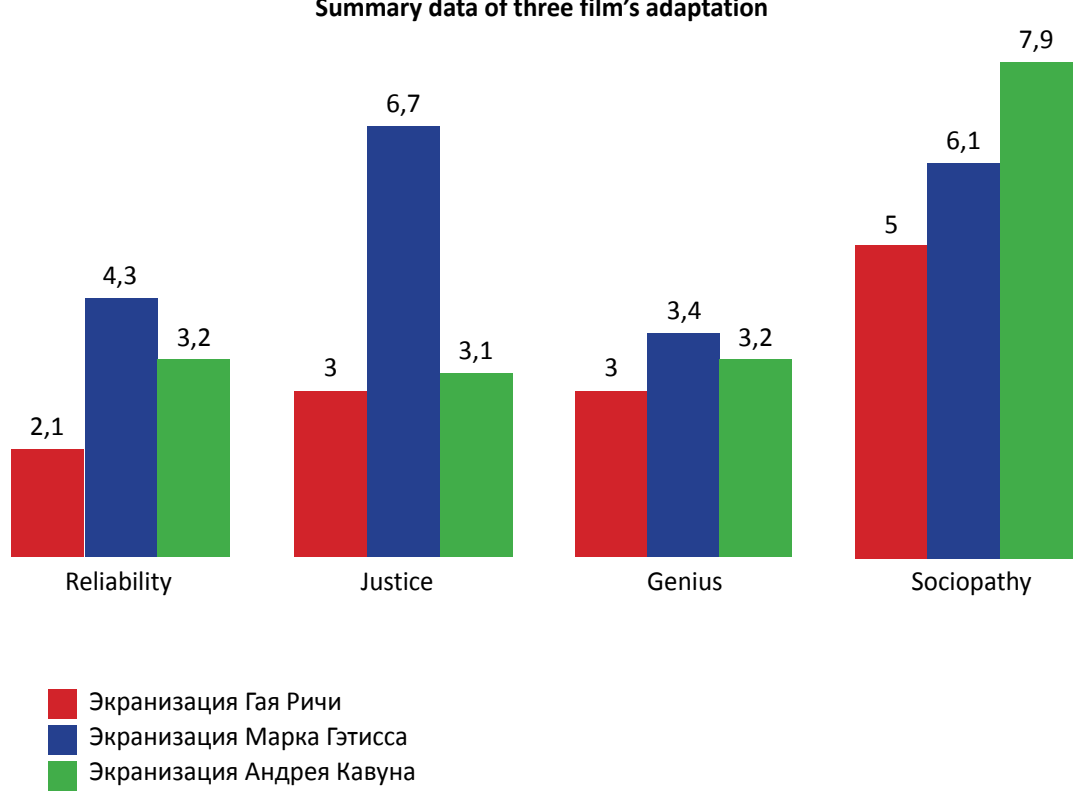

Fig. 9. Summary data of three film's adaptation 


\section{CONCLUSIONS}

Our study of the character's representation on the examples of three film adaptations of the works about Sherlock Holmes allows us to draw the following conclusions:

1. Specific conclusions: in modern film adaptations sociopathy and neurasthenia prevail over genius, which, on the one hand, gives cinematographers an opportunity to expand the static characteristics of the image, but, on the other hand, narrows the field of representation by sociopathy itself, not allowing the character to implement the social function of ideas of higher justice, the triumph of scientific thinking and rationalism, the important components of the myth related to Sherlock Holmes. In all the three film adaptations, the character is explicitly driven not by the idea of the triumph of justice (indeed, even the canonical Sherlock investigates another case for the sake of an intellectual challenge), but by personal motives, mostly connected with love (particularly expressed in A. Kavun's adaptation in the story of the tragic love of Holmes and Irene Adler, only slightly outlined in A. Conan Doyle's story Scandal in Bohemia), emotional and sentimental, which leads to a certain distortion of the archetype. In their turn, such representations are perceived by the viewer (often not familiar with the literary source) not as new screen versions of A. Conan Doyle's works, but as independent works with an original plot. The limited interaction of the introverted hero with society also leads the filmmakers to the necessity of creating an image of a stronger intermediary between the character and society, whose role Watson actually plays in all the three film adaptations. Therefore, Holmes's faithful acolyte is more appealing to the audience than the sociopathic protagonist. Moreover, in A. Kavun's film Watson practically becomes a kind of a new Pygmalion: the image of his friend, created by Watson, acquires the canonic Holmes features from S. Paget's drawings in the final part of the series. And Holmes himself obeys the artistic will of his creator.

2. General conclusions: modern film adaptations reveal an attempt to radically reinterpret the archetype, which to a certain extent has influenced several generations (Holmes not only as an embodiment of higher justice, but also as a harmonizing force in the neo-Victorian discourse), by absurdizing the image of the character. This includes mockery and simplification of the character: for example, in Will Ferrell's American parody comedy Holmes \& Watson (2018) or Rachel Lee Goldenberg's mockbuster Sir Arthur Conan Doyle's Sherlock Holmes (2010), which received an extremely negative reaction 
from the audience. Such adaptations are not only considered unsuccessful, but even displeased the British Royal Court [11, p. 47]. Moreover, the very attempt to mock the archetypal character and the destruction of the Holmes's myth leads to the career failures of actors and to the oblivion of such adaptations from the side of the viewers. Sherlock Holmes still inspires filmmakers both as a social phenomenon and as a timeless image, a myth from literature, being open to improvisation even taking into account its static characteristics. Here, in our opinion, there are two ways: to be careful and correct about the style, the essence of the original source and the literary and cinematic myth, or to create a completely new style of narration and a new image, like Guy Ritchie, who shot both films about Holmes in steampunk style, and Andrey Kavun and Nurbek Egen. However, the idea of higher justice, an important component of the literary myth and the screen image of Holmes as a superhero. Nikita Kartsev compares Holmes to the superheroes of Marvel Universe but not wearing the costume and the mask of Batman or the armor of Iron Man, should not, in our opinion, be vulgar, silly, or ridiculous. It is one of the accepted social fundamental values, and Sherlock Holmes embodies this justice for several generations of readers and viewers. Unfortunately, from our point of view, modern film adaptations are going not only further and further both from the original literary source (in the cited review of Guy Ritchie's film A. Anastasiev writes that the main characters could be called Tarapunka and Shtepsel) and from the recognized classic film adaptations, but they are getting more and more controversial. The mentally unhealthy Sherlock Holmes (Elementary by Michael Cuesta, Fig. 10), the exalted, almost hysterical neurotic (Sherlock Holmes by Andrey Kavun) can a priori represent neither ultimate justice, nor a rational balancing force, which is the reason why the screen image falls out of the archetype: all the strange Sherlocks ("Same but completely different") is the slogan of Andrey Kavun's series) are not perceived as heroes, but only as a succession of simplified versions. 


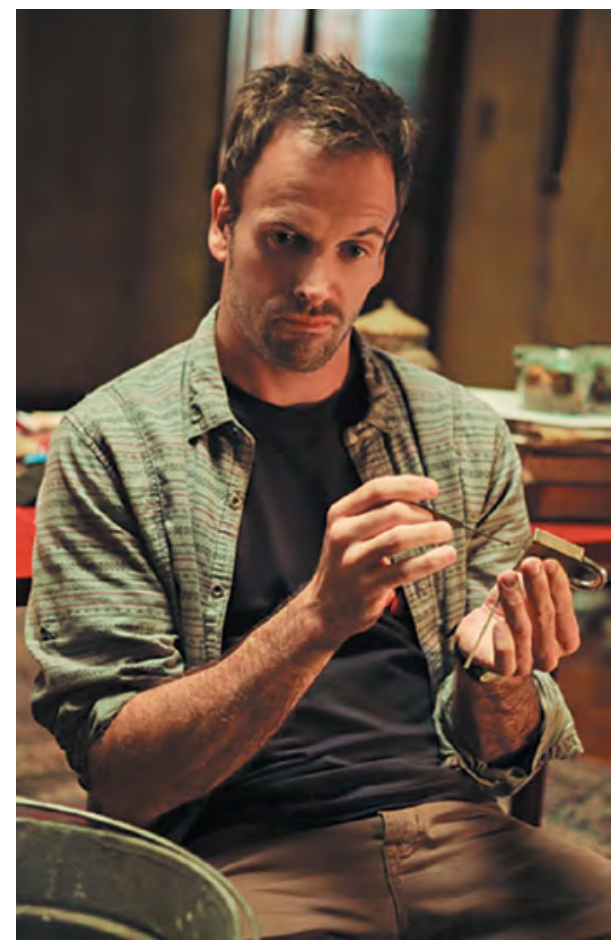

Fig. 10. Sherlock Holmes performed by American actor Johnny Lee Miller.

A shot from the detective series Elementary, based on the characters in Arthur Conan Doyle's books about Sherlock Holmes, takes place today.

The premiere took place on CBS on September 27, $2012^{8}$

Further research into the dynamics of social characteristics, belonging to a screen sociopathic character of such scale as Sherlock Holmes, is promising. Analyzing interpretations of both the literary myth and its screen embodiment is of undoubted scientific interest, as they reflect the state of society itself, the transformation of its moral, ethical and aesthetic values.

This paper has been supported

by the RUDN University Strategic Academic Leadership

Program

\footnotetext{
${ }^{8}$ See the image source: $h$ ttps://www.kino-teatr.ru/kino/acter/m/euro/59398/foto/m100008/356360/ (08.07.2021).
} 


\section{REFERENCES}

1. Razlogov K.E. (Ed.). Ekrannaya kul'tura: Teoreticheskie problem [Screen culture: Theoretical problems]. Saint-Petersburg: Dmitriy Bulanin, 2012. 752 p.

2. Yushchenko O.I., \& Gamaleyeva Yu.A. Khudozhestvennyy kinematograf i ego rol' $v$ formirovanii obraza natsional'nogo geroya na primere lichnosti Uinstona Cherchillya [Art cinema and its role in shaping the image of a national hero on the example of the personality of Winston Churchill]. Istoriya i sovremennoe mirovozzrenie [History and Modern Worldview]. 2020. 2 (3), pp. 119-123. https://urvak.ru/articles/istor-4577vypusk-3-khudozhestvennyy-kinematograf-/

3. Eisenstein S.M. O chistote kinoyazyka [On the purity of the film language]. In S.M. Eisenstein, Izbrannye proizvedeniya [Selected works] (Vol 2, pp. 81-92). Moscow: Iskusstvo, 1964.

4. Kuleshov L.V. Rabota operatora [Operator's work]. In L.V. Kuleshov, Iskusstvo kino: Moy opyt [The art of cinema: My experience] (pp.75-95). Leningrad: Tea-kinopechat', 1929.

5. Yankovskiy A.N. Igra "kvest" kak sintez literaturnykh i kinematograficheskikh traditsiy [A "quest" game as a synthesis of literary and cinematic traditions]. Kul'tura $i$ iskusstvo [Culture and Art]. 2018. (9), pp. 50-59. https://doi.org/10.7256/24540625.2018.9.27465

6. Kolotayev V.A., \& Markov A.V. Problematizatsiya fenomena kinoidentichnosti v issledovaniyakh kinoiskusstva [Problematization of the film identity as a phenomenon in the cinema art studies]. Artikul't [Art\&Cult]. 2019. (3), pp. 130-145. https://doi. org/10.28995/2227-6165-2019-3-130-145)

7. Shapinskaya E.N. Ekzistentsial'nyy drugoy: Refleksii i reprezentatsii [The existential other: Reflections and representations]. Kul'tura kul'tury [Culture of culture]. 2019. (4), pp. 2-16.

8. Polasek A.D. The evolution of Sherlock Holmes: Adapting character across time and text. Faculty of Art, Design, and Humanities. De Montfort University. 2014. 316 p.

9. Naidu S. Sherlock Holmes in Context. London: Palgrave MacMillan, 2020. 137 p.

10. Buchmann A. The mediatization of Sherlock Holmes. In M. Månsson, A. Buchmann, C. Cassinger, \& L. Eskilsson (Eds.), The Routledge companion to media and tourism (pp. 326-336). Routledge. 2020.

11. Benette L., Hwang D. The adventures of Sherlock Holmes. London: CoPublished with Ws Education (Children's). 2021. 127 p.

12. Anastas'ev A. Ischeznovenie Sherloka Holmsa: "Sherlok Holms", rezhisser Gaj Richi [The disappearance of Sherlock Holmes: "Sherlock Holmes," Guy Ritchie directed]. Iskusstvo kino [Kinoart]. 2010. (1), p. 54-60. https://old.kinoart.ru/archive/2010/01/ n1-article11 (accessed 03.07.2021)

13. McCaw N. Sherlock Holmes and a politics of adaptation. In S. Vanacker, C. Wynne (Eds.), Sherlock Holmes and Conan Doyle (pp. 36-48). Palgrave MacMillan, Second Edition. 2020. 
14. Tynyanov Yu.N. Ob osnovakh kino [On the basics of cinema]. In B.M. Eichenbaum (Ed.), Poetika kino [The poetics of cinema] (pp. 55-85). Moscow-Leningrad: Kinopechat'. 1927.

15. Shklovskiy V.B. Revolyutsiya media [The media revolution]. In V.B. Shklovskiy, Sobranie sochineniy [Collection of works] (Vol. 1, pp. 709-871). Moscow: Novoe literaturnoe obozrenie, 2018.

16. Eisenstein S.M. Za kadrom [Out of vision]. In S.M. Eisenstein, Izbrannye proizvedeniya [Selected works] (Vol 2, pp. 283-297). Moscow: Iskusstvo, 1964.

17. Kuleshov L.V. O stsenarii [About the script]. In L.V. Kuleshov, Iskusstvo kino: Moy opyt [The art of cinema: My experience] (pp. 99-112). Leningrad: Tea-kinopechat', 1929.

18. Lotman Yu.M. Syuzhet $v$ kino [The plot in the movie]. In Yu.M. Lotman, Semiotika kino i problemy kinoestetiki [Cinema semiotics and aesthetic problems in cinema] (pp. 38-46). Tallin: Eesti Raamat, 1973.

19. Os'mukhina O.Yu. Obraz geroya-detektiva: spetsifika interpretatsii literaturoy i sovremennym kinematografom [The image of a detective hero: The interpretation specifics in literature and modern cinema]. Filologicheskie nauki: Voprosy teorii $i$ praktiki [Philological Sciences: Issues of Theory and Practice]. 2019. 12 (2), pp. 389-393. https://doi.org/10.30853/filnauki.2019.2.83

20. Savel'eva T.V. Mediynyy obraz uchenogo - fol'klorista, etnografa, antropologa, lingvista na primere rossiyskikh i zarubezhnykh kinofil'mov [Media image of a folklore scientist, ethnographer, anthropologist, linguist on the example of Russian and foreign films]. Znak: problemnoe pole mediaobrazovaniya [Sign: Problematic field of media education]. 2018. Issue 2 (28), pp. 214-221.

21. Shapinskaya E.N. Monstr kak kul'turnyy geroy: reprezentatsiya monstruoznosti v massovoy kul'ture [The monster as a cultural hero: The representation of monstrousness in popular culture]. Kul'tura kul'tury [Culture of culture]. 2019. (2), pp. 1-13.

22. Kracauer S. Priroda fil'ma: Reabilitatsiya fizicheskoy real'nosti [Theory of film: The redemption of physical reality]. Moscow: Iskusstvo, 1974. 442 p.

23. McFarlane B. Novel to film: An introduction to the theory of adaptation. Wotton-under-Edge: Clarendon Press, 1996. 296 p.

24. Egiazarova I. Retsenziya na serial "Sherlok v Rossii": Paradnyy vykhod Bogomolova, postel'naya stsena s Matveevym i portsiya kulinarnogo yumora [Review of the series "Sherlock in Russia:" Bogomolov's grand entrance, Matveev in a bedroom scene and a portion of culinary humor]. Vokrug TV [Around TV]. 22.10.2020. https:// doi.org/10.30853/filnauki.2019.2.83 (accessed 03.07.2021)

25. Kartsev N. Trubka, shlyapa i Vatson-vot moi dokumenty [Pipe, hat and Watson-these are my documents]. GQ. 19.11.2013. https://www.gq.ru/ entertainment/trubka-shlyapa-i-vatson-vot-moi-dokumenty (accessed 24.06.2021) 
ABOUT THE AUTHORS

\section{BELLA A. BULGAROVA}

PhD (in Philology), Associate Professor

at the Mass Communications Department,

Peoples' Friendship University of Russia (the RUDN University),

Miklukho-Maklaya, 10, bldg. 2, 117198, Moscow

ResearcherID: G-3631-2016

ORCID: 0000-0001-6005-2505

e-mail: bulgarova-ba@rudn.ru

\section{ALEXEY YU. OVCHARENKO}

D.Sc. (in Philology), Associate Professor

at the Department of Russian Language,

Head of the Department of Linguodidactics and Testology,

Peoples' Friendship University of Russia (the RUDN University),

Mlukho-Maklaya, 6, 117198, Moscow

ORCID: 0000-0002-8544-5812

ResearcherID: Z-3696-2019

e-mail: ovcharenko_ayu@pfur.ru

\section{VICTOR V. BARABASH}

D.Sc. (in Philology), Professor at the Mass Communications Department, Dean of the Faculty of Philology,

Peoples' Friendship University of Russia (the RUDN University),

Miklukho-Maklaya, 10, bldg. 2, 117198, Moscow

ResearcherID: P-6349-2017

ORCID: 0000-0002-8909-2145

e-mail: barabash-vv@rudn.ru

JULIA A. VOROPAEVA

$\mathrm{PhD}$ (in Pedagogical Sciences), Associate Professor

at the Department of Russian Language,

Peoples' Friendship University of Russia (the RUDN University),

Miklukho-Maklaya, 6, 117198, Moscow

ResearcherID: AAN-5202-2020

ORCID: 0000-0002-5425-3359

e-mail:voropaeva_yua@pfur.ru 
УДК $791.4+008$

ББК 85.373(0) + 71.04

DOI: $10.30628 / 1994-9529-2021-17.2-171-213$

received 30.05.2021, accepted 29.06.2021

БЕЛЛА АХМЕДОВНА БУЛГАРОВА

Российский университет дружбы народов,

Москва, Россия

ResearcherID: G-3631-2016

ORCID: 0000-0001-6005-2505

e-mail: bulgarova-ba@rudn.ru

АЛЕКСЕЙ ЮРЬЕВИЧ ОВЧАРЕНКО

Российский университет дружбы народов,

Москва, Россия

ResearcherID: Z-3696-2019

ORCID: 0000-0002-8544-5812

e-mail: ovcharenko_ayu@pfur.ru

ВИКТОР ВЛАДИМИРОВИЧ БАРАБАШ

Российский университет дружбы народов,

Москва, Россия

ResearcherID: P-6349-2017

ORCID: 0000-0002-8909-2145

e-mail: barabash-vv@rudn.ru

ЮЛИЯ АЛЕКСАНДРОВНА ВОРОПАЕВА

Российский университет дружбы народов, Москва, Россия

ResearcherID: AAN-5202-2020

ORCID: 0000-0002-5425-3359

e-mail:voropaeva_yua@pfur.ru 


\section{«КАЖДОМУ ПОКОЛЕНИЮ -}

\section{СВОЙ ШЕРЛОК»: ОБРАЗ ГЕРОЯ}

\section{В ЭКРАНИЗАЦИЯХ ПРОИЗВЕДЕНИЙ}

\section{А. КОНАН ДОЙЛА О ШЕРЛОКЕ ХОЛМСЕ}

Аннотация. Статья посвящена проблеме воплощения образа главного героя в современном кинематографе в наиболее поздних экранизациях произведений А. Конан Дойла. Актуальность данной научной проблемы обусловлена тем, что специфика репрезентации героя в современном кинематографе отражает состояние самого общества, его социальные проблемы, фобии и неврозы. Кинематограф, как ни один другой вид современного искусства, имеет огромные возможности для воплощения любого персонажа в трехмерной реальности, что налагает определенную социальную ответственность за создание образа главных героев. Обращение к архетипическим образам мировой литературы предполагает не только открытость импровизаций, но и сохранение социальной функции героя. В статье анализируется репрезентация одного из таких архетипических образов мирового значения - Шерлока Холмса. Методология исследования основана на системном подходе и общенаучных методах, а также включает специальные методы: контент-анализ научной литературы по теме исследования; метод социологического опроса (анкетирование), метод статистического анализа. В качестве материалов эмпирического исследования, результаты которого приведены в настоящей статье, использованы три экранизации рассказов о Шерлоке Холмсе, созданные в 2000-х годах в Великобритании, России и США. В исследовании приняли участие 150 респондентов, ответы которых были переведены из качественного в количественный формат для анализа специфики репрезентации героя (протагониста). Авторы статьи пришли к следующим выводам: в современных экранизациях герой представлен не как гений научного метода мышления, а как социопат, который не в состоянии взаимодействовать с обществом без посредника (персонажа-спутника). Более того, в современных экранизациях нарушается сам архетипический образ благодаря импровизациям со статическими характеристиками героя, что вызывает негативное восприятие такого героя зрителями. Сами по себе усиление социопатических черт характера героя, смещение акцента с идеи высшей справедливости, от вечных ценностей к частным мотивам, приводят к определенному упрощению героя, а также служат индикатором состояния самого общества. Теоретическая значимость исследования опреде- 
ляется тем, что в данной статье предложены авторские критерии анализа репрезентации героя. Практическая значимость статьи заключается в том, что выводы и результаты исследования могут быть использованы для дальнейших работ по выявлению влияния воплощения героев на формирование ценностных ориентаций современного общества.

Ключевые слова: кинематограф, герой, персонаж, импровизация, статические характеристики героя, динамические характеристики героя, социальная функция, архетипический образ, способы репрезентации

\section{ВВЕДЕНИЕ}

Актуальность темы исследования обусловлена тем, что проблема репрезентации главного героя (протагониста) является индикатором эстетических, морально-этических и ментальных характеристик современного общества. Наиболее мощными инструментами для этого, несомненно, обладает современный кинематограф как часть общей экранной культуры [1], позволяющий транслировать созданные образы всему миру, тиражировать и визуализировать литературные и национально-политические мифы [2, с. 119]. Повсеместное распространение кинематографа, его современные цифровые версии и широкий набор выразительных средств определяет уникальность и особую силу воздействия этого вида искусства на современный мир.

Создатели фильма используют определенные приемы формирования и развития персонажей. Выбор техники съемки, действия, мизансцены, монтажа, освещения и звука, - все это определяет художественный способ конструирования образа героя на основе симбиоза авторской мысли и кинематографических техник. Процесс трансформации художественного образа в образ экранный основан на специфическом кинематографическом драматургическом каноне. И мизансцена - цветовое решение и освещение, костюмы, грим, расстановка реквизита, размещение актеров на площадке, и сама композиция кадра несут определенную информацию о персонаже, на что еще в 1920-1930-х гг. обращали внимание С.М. Эйзенштейн [3, с. 81-93] и Л.В. Кулешов [4, с. 75-95]. Создатели фильма тщательно продумывают последовательность кадров, темп монтажа и использование техник редактирования, также влияющих на повествование, репрезентацию героя и вовлеченность аудитории в экранное действие. Обрезка звука с совпадением, редактирование непрерывности, обрезка рамки кадра, вставка, растворение, постепенное появление, исчезновение, быстрое движение, переход, наложение - все это приемы 
монтажа, также вносящие свой вклад в создание образа героя [5, с. 50]. В большинстве художественных фильмов, хотя освещение может выглядеть обычным и естественным, создатели фильма прилагают немало усилий, чтобы добиться нужного им определенного светового эффекта. Освещение всегда вносит значительный и значимый вклад в повествование - немецкий экспрессионизм и фильмы жанра «нуар» с их полумраком, игрой теней и боковым освещением лиц героев, - классические примеры. Создатели фильма тщательно продумывают качество и расположение источников света, оказывающие влияние на повествование и развитие персонажей [6, с. 130].

Подобно тому, как создатели фильма продумывают визуальное редактирование фильма, звуковые ряды в кинокартине также тщательно продуманы. Звуковые эффекты и музыкальное сопровождение также вносят существенный вклад в создание экранного образа героя. По мнению большинства исследователей современной кинематографии, репрезентацию героя в фильме также можно описать формулой: «диалог + физическое движение = персонаж» [7, с. 2].

Это подводит нас к главной составляющей фильма - его героям. Отождествление с персонажами - частая причина, по которой люди любят определенный фильм. Зритель хочет, чтобы протагонист и второстепенные персонажи развивались так же, как люди в реальной жизни. Чтобы фильм мог отразить это развитие, персонаж должен показать эволюцию моральных и этических качеств, таких как порядочность, честность или храбрость, а также «иметь хорошо детализированную биографию, которая делает персонаж трехмерным» [5, с. 54].

Чтобы создать трехмерный персонаж с хорошо проработанным фоном, фильм должен иллюстрировать социологию, психологию и физиологию героя. Поскольку фильм - это визуальный опыт, социология и психология, наряду с физиологией, тонко изображаются визуально с помощью физических движений и диалогов герой в любой конкретной ситуации фильма.

При создании образа героя в кинематографии физические действия и диалог героя меняются в зависимости от экспозиции и конфликта по мере того, как он или она проходит через восходящие и нисходящие действия фильма. Каждый кадр фильма должен быть направлен на то, чтобы завершить действие и развить историю героя. Кроме того, диалог в этих ситуациях должен согласовываться с физическими движениями. Напри- 
мер, диалог «не может быть разглагольствованием и бредом по поводу конкретной ситуации, когда персонаж спокойно стоит, глядя в окно» [8, c. 102].

В истории кинематографа насчитывается множество примеров репрезентации литературного героя, однако на сегодняшний день наиболее ярким и интернациональным образом для воплощения на экране служит, как это ни парадоксально, герой, созданный еще два столетия назад и до сих пор успешно завоевывающий внимание зрителей - Шерлок Холмс. Этот герой считается архетипом - образом, согласно известным идеям К.-Г. Юнга, несущим в себе социальную идею, значимую для всего человечества во все периоды исторического развития, понятную в любой национальной культуре и отвечающую морально-этическим запросам общества [9, с. 9]. В случае с Шерлоком Холмсом сформировавшийся в конце $\mathrm{XIX}$ - первой половине XX в. архетип выражает идею высшей справедливости, которую способен реализовать человек с помощью научного анализа.

Анализируя этот вневременной образ, некоторые исследователи отмечают, что "Шерлок Холмс - это один из самых адаптированных персонажей всех времен» [8, с. 17]. Феномен этого героя заключается в том, что он представляет собой не только архетипический образ, понятный и доступный для любой культуры и нации, но и фактически миф Холмса, вобравший в себя интертекстуальность предыдущих экранных воплощений, своеобразный «канон Холмса». В научной литературе было сделано немало попыток анализа феномена этого героя: от исследования дискретного перехода текста от страницы к экрану [8, с. 18] до эволюции персонажа по мере его изменения в различных интертекстах и во времени [10, с. 226]. При этом исследователи стремились показать, что адаптируется именно персонаж, а не литературный текст с его повествовательными, жанровыми и эстетическими характеристиками, и что с учетом этого, изучение экранной репрезентации Шерлока Холмса должно включать изучение различных аспектов кинематографии, которые формируют, изменяют и определяют этого героя на протяжении сотен его экранных жизней. На сегодняшний день мировой кинематограф насчитывает 135 кинематографических воплощений Шерлока Холмса, созданных актерами разных стран (Великобритания, Россия, США, Канада, Польша, Япония и др.) [11, с. 44] (Рис. 1). 


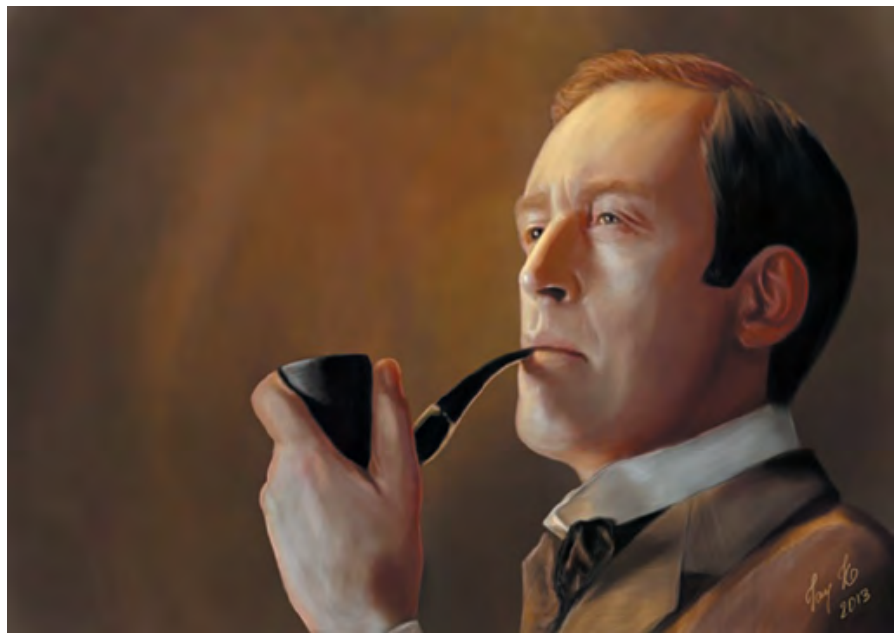

Рис. 1. Канонический образ советского кинематографа - Шерлок Холмс в исполнении В.Б. Ливанова. Кадр из телевизионного фильма цикла «Приключения Шерлока Холмса и доктора Ватсона».

Реж. Игорь Масленников, 1979-19861

Исследование архетипического образа Шерлока Холмса в контексте его кинематографических репрезентаций позволяет, на наш взгляд, выявить основные особенности современной трактовки персонажа и раскрыть специфику отношения к герою современного общества. Существуют различные точки зрения на специфику воплощения экранного образа Шерлока Холмса. Так, в работе А. Бахманн выдвинут следующий тезис: «Бесчисленные переосмысления затронули все аспекты характера и мира Холмса - костюм, внешность, период времени, пол, сексуальность - но одно никогда не меняется: он ученый. Этот герой представляет собой смесь всех стереотипов, которые когда-либо были у нас в отношении ученых - одиноких, интровертированных, смелых, безрассудных, немного бесчеловечных, жестоких, одержимых, творческих и блестящих» $[10$, c. 329]. Это утверждение можно взять за основу для анализа особенностей репрезентации героя, поскольку тот мир, в котором он изначально был создан, был в буквальном смысле одержим наукой. В викторианскую эпоху была создана первая «вычислительная машина» Чарльза Бэббиджа, предшественница современных компьютерных технологий. Многие

${ }^{1}$ Источник изображения см.: URL: https://aif.ru/culture/movie/1076684 (08.07.2021). 
литературные предшественники Холмса, герои-детективы - Дюпен Эдгара А. По, Лекок Эмиля Габорио, «Мыслительная машина» - профессор Ван Дузен Жака Футреля - были персонажами, которые гордились своим систематическим, безэмоциональным подходом к решению сложных загадок [12, с. 38].

Герой сэра А. Конан Дойла, Шерлок Холмс в его классической версии также отличался отсутствием эмоций. (Интересно, что в британском литературном детективе присутствует и полная противоположность Холмса - патер Браун Г.-К. Честертона, в расследованиях преступлений полагающийся не на логику, а на знание человеческой природы. Экранизация рассказа «Сапфировый крест» - «Отец Браун» Роберта Хеймера (1954) с Алеком Гиннессом в заглавной роли считается эталонной. Сопоставление кинематографической репрезентации образов патера Брауна, в том числе в сериале BBC One «Отец Браун» (2013-2020) и Холмса - тема для дальнейших исследований (Рис. 2).

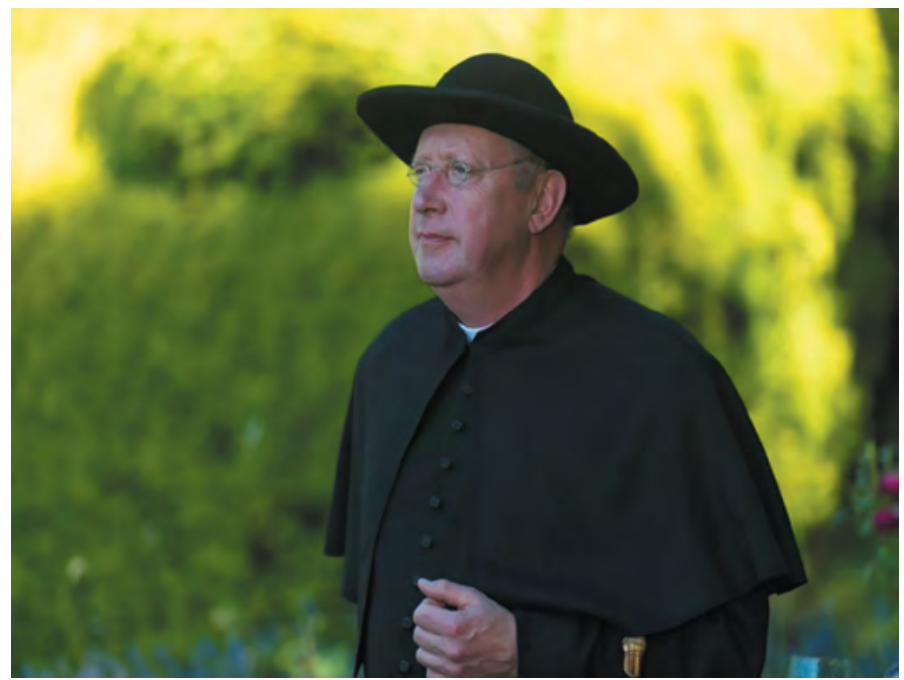

Рис. 2. Отец Браун в исполнении Марка Уильямса. Кадр из сериала BBC One «Отец Браун» (2013-2020).

Сериал снят по мотивам произведений Гилберта Кита Честертона о католическом священнике-детективе отце Брауне ${ }^{2}$

\footnotetext{
2 Источник изображения см.: URL: https://www.kino-teatr.ru/kino/movie/euro/117224/foto/864506 (08.07.2021).
} 
Как и в случае с машиной Бэббиджа, здесь участвует не личность, а только применение метода. Но, видимо, как хорошо знал А. Конан Дойл, ни один ученый, не говоря уже о популярном литературном персонаже, не может выжить благодаря только холодной механической логике $[12$, с. 39]. Упорный, лишенный воображения собиратель фактов - не единственный наш стереотип изображения ученого. Холмс также является замкнутым, эксцентричным, человеком, полагающимся на интуицию и таинственные вспышки проницательности. В некоторых случаях он полностью «отказывается от своих дедуктивных методов и выбирает старые добрые кулачные бои» [12, с. 40]. Объединяя эти, казалось бы, противоречивые характеристики, Холмс становится более реалистичным ученым и человеком, чем любой из его вымышленных соперников. Он также хорошо поддается адаптации - каждый режиссер создает свой образ Холмса, руководствуясь каноническим набором личностных качеств литературного героя. Как пишет Н. МакКау: «Некоторые подчеркивают в этом герое злоупотребление наркотиками, другие - игру на скрипке, третьи - остроумие. Р. Дауни-младший сосредотачивается на своей физической форме, Джереми Бретт был тихо таинственным, Бэзил Рэтбоун был классическим джентльменом, а Холмс Б. Камбербэтча блестящий интеллектуал. Но все они ученые, потому что никогда не меняются метод и цель» [12, с. 46]. Персонаж А. Конан Дойла, таким образом, не имеет четких, замкнутых характеристик героя, что оставляет практически безграничную свободу для его интерпретаций, представляя собой своеобразный кинематографический палимпсест.

Этот аспект, возможно, и лежит в основе увлечения Холмсом как героем в современном кинематографе, особенно в его неовикторианской версии, обладающей и терапевтическим эффектом: зрителя утешает мысль о том, что, какой бы таинственной ни была загадка, есть решение, которое кто-то способен найти и найдет обязательно, что Холмс для решения проблем использует логику, воображение и помощь добровольных помощников - уличных мальчишек, а не полагается на искусственный интеллект. В рецензии на фильм Гая Ричи А. Анастасьев, тем не менее, подчеркивает, что в фильме переданы общественные настроения и запросы массовой культуры 2000-х гг. и на антинауку, и на всякого рода мистику [12].

Однако, в трех наиболее поздних экранизациях - «Шерлок» с Б. Камбербэтчем (2010-2017) (Рис. 3), «Шерлок Холмс» (2009) и «Шерлок Холмс: игра теней» с Р. Дауни-младшим (2011) (Рис. 4), и «Шерлок Холмс» с И. Петренко (2013) (Рис. 5) зрительская любовь к Холмсу, как и к науке, 


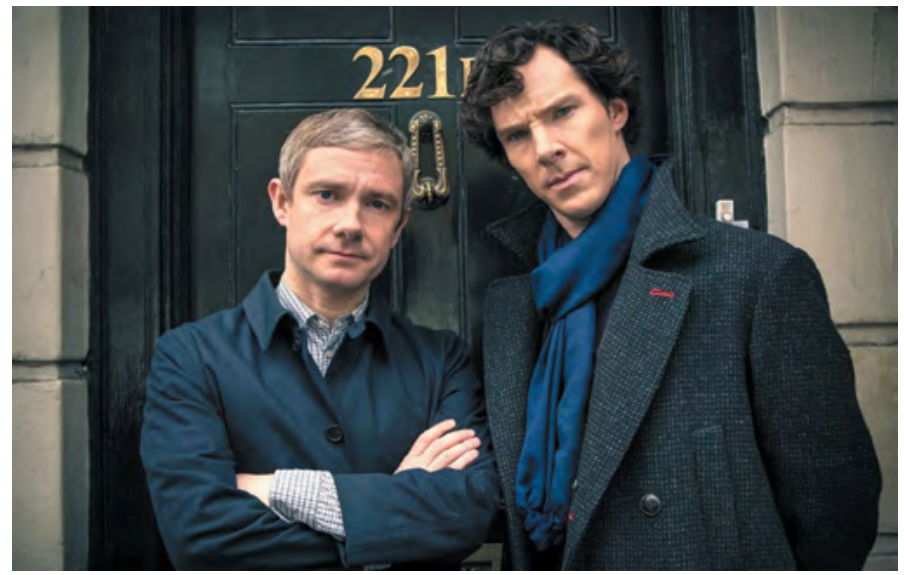

Рис. 3. Шерлок Холмс в исполнении Бенедикта Тимоти Карлтона Камбербэтча. Кадр из британского телесериала компании Hartswood Films, снятого для BBC Wales. Сюжет основан на произведениях сэра Артура Конан Дойля о детективе Шерлоке Холмсе, однако действие происходит (за исключением одной серии) в наши дни (2010-2017) гг. ${ }^{3}$

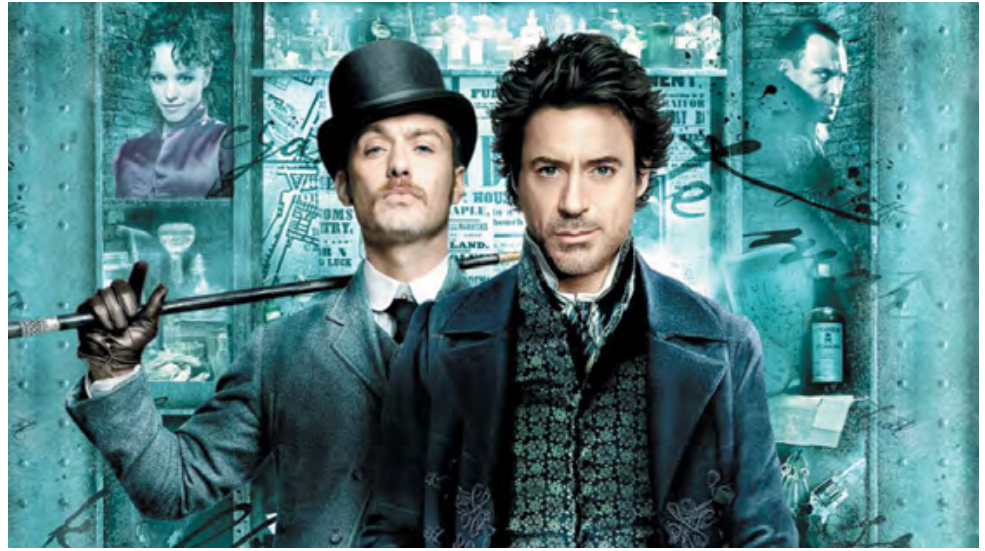

Рис. 4. Шерлок Холмс в исполнении Роберта Дауни младшего.

Кадр из американского фильма «Шерлок Холмс» (англ. Sherlock Holmes) детективный боевик режиссера Гая Ричи, в основе которого лежат произведения

Артура Конан Дойля о Шерлоке Холмсе, хотя основной сюжет оригинален.

Премьера фильма состоялась 24 декабря (в России - 31 декабря) 2009 года ${ }^{4}$.

\footnotetext{
${ }^{3}$ Источник изображения см.: URL: sherlock-serial-sherlock-bbc-sherlock-holmes-sherlock-she-39.jpg (1332×850) (goodfon.ru) (08.07.2021).

${ }^{4}$ Источник изображения см.: URL: https://thumbs.dfs.ivi.ru/storage28/contents/9/8/28252fd2c21f9ed 09083fa0f8fb086.jpg (08.07.2021).
} 


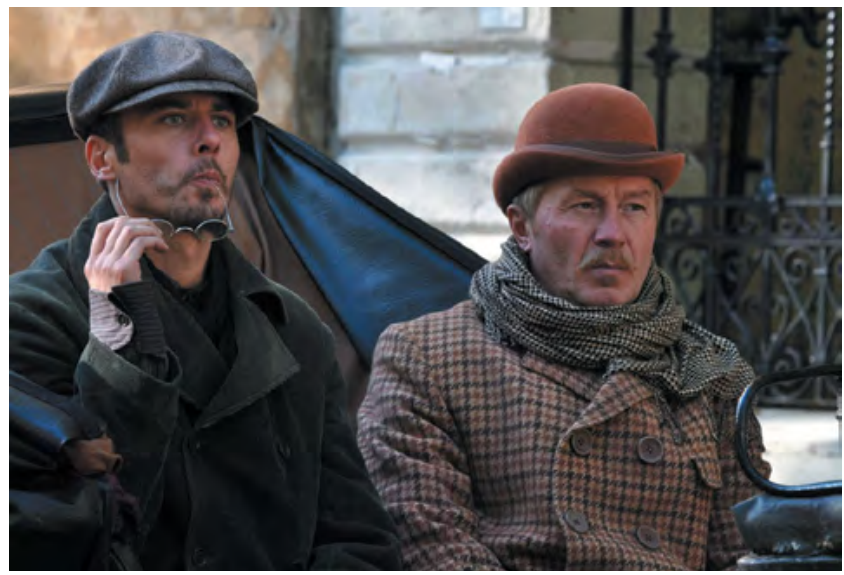

Рис. 5. Шерлок Холмс в исполнении российского актера Игоря Петренко.

Кадр из российского телесериала производства кинокомпании «Централ партнершип», снятого режиссером Андреем Кавуном

по мотивам рассказов Артура Конана Дойла о сыщике Шерлоке Холмсе.

Премьера фильма состоялась с 18 по 28 ноября 2013 года на телеканале «Россия-1»5.

омрачена опасениями: по репрезентациям этого героя в данных фильмах не очень ясно, насколько далеко он может зайти в поисках истины. Если принять во внимание, что архетип Шерлока Холмса выражен не только в общекультурной идее вечного торжества справедливости, но и воспринимался на протяжении почти всего XX в. как рациональное и научное начало $[11$, с. 65-66]. то важно установить, как именно формируется репрезентация данного героя в современном кинематографе, каким видят современные зрители героя и, соответственно, как современное общество представляет себе высшую справедливость и нуждается ли оно в ней.

Научная литература по проблемам экранизации достаточно обширна, имеет долгую традицию, и включает работы как отечественных, так и зарубежных авторов. Теоретические основы взаимоотношения литературы и кино заложены русскими формалистами Ю.Н. Тыняновым [14, с. 55-85], В.Б. Шкловским [15, с. 709-871], близкими к их кругу С.М. Эйзенштейном [16, с. 283-297] и л.В. Кулешовым [17, с. 99-112] и др. Эти идеи получили дальнейшее развитие в более поздних работах Ю.М. Лотмана $[18$, с. 38-46].

\footnotetext{
${ }^{5}$ Источник изображения см.: URL: https://rg.ru/2013/12/31/holms-site.html (08.07.2021).
} 
Более частной проблеме - репрезентации героя в кинематографе, посвящены работы российских авторов В.А. Колотаева, А.В. Маркова [6], О.Ю. Осьмухиной [19], Т.В. Савельевой [20], Е.Н. Шапинской [7, 21], О.И. Ющенко, Ю.А. Гамалеевой [2], А.Н. Янковского [5].

Зарубежные исследователи проблем экранизации (адаптации) литературных произведений, начиная с классической книги 3. Кракауэра «Природа фильма: реабилитация физической реальности» (1960), рассматривают как общетеоретические проблемы взаимоотношения литературы и кино: 3. Кракауэр пишет о кинематографичности литературного произведения и об ограниченности возможностей киноязыка для сохранения духа литературного источника [22, с. 313, 316], так и более конкретные вопросы: например, Б. Макфарлейн пишет о двух разных языках - литературного источника и режиссера для рассказа одной и той же истории, различая повествование (сюжет источника) и высказывание (кинематографическую интерпретацию), stories told - stories presented [23, p. 70]. Однако, в большинстве работ делается акцент на репрезентацию образа героя в кинематографе. В работах таких авторов, как Л. Бенетт, Д. Хван [11], А. Бахманн [10], Н. МакКау [12], С. Найду [9] и А.Л. Полачек [8] представлены оригинальные авторские методики анализа кинематографических репрезентаций героя на основе эмпирических исследований. Тем не менее в современной научной литературе до сих пор не проводился анализ критериев оценки репрезентации героя и ее восприятие зрителем. С этой позиции представленное в статье исследование имеет определенную научную новизну и дополняет отечественную научную литературу по исследуемой теме.

\section{МЕТОДЫ И МАТЕРИАЛЫ}

Методология исследования основана на системном подходе, включающем методы общенаучной группы (анализ, синтез, дедукцию, индукцию), а также ряд специальных методов: контент-анализ научной литературы по теме исследования; метод социологического исследования (метод механической выборки и анкетирования) и метод статистического анализа данных.

Контент-анализ научной литературы по теме исследования позволил выявить два критерия оценки репрезентации героя:

1. Статические (неизменные) базовые характеристики:

происхождение героя, внешность и атрибутика (кепка, трубка, плащ, 
скрипка) ${ }^{6}$, спутник протагониста (Дж. Ватсон). Несмотря на то, что в сериале "Элементарно» (2012-2018) персонаж Ватсона представлен женщиной, как исключение из классического набора статических характеристик архетипа, спутник героя всегда присутствует как постоянная величина.

2. Динамические:

привычки героя, проявления характера, морально-этические убеждения. Эти характеристики изменчивы в социально-историческом контексте почти столетней истории экранизаций Шерлока Холмса. Причем все наиболее поздние версии представляют героя почти как откровенного социопата (Шерлок в исполнении И. Петренко наиболее яркий пример).

Для формирования обобщающей оценки специфики репрезентации героя нами был проведен мини-опрос в социальной сети Twitter в группе «Современное кино». Анкета содержала шесть вопросов (три вопроса по каждому выделенному нами критерию репрезентации).

\section{МАТЕРИАЛЫ ИССЛЕДОВАНИЯ}

В качестве объекта исследования нами были отобраны три наиболее поздних экранизации («Шерлок в России», 2020, режиссер Нурбек Эген, не экранизация в полном смысле; сериал был снят по оригинальному сценарию, представляющему вольную интерпретацию классического образа Шерлока Холмса, о чем пишет в своей рецензии Илона Егиазарова [24]), выстроенных в опросе в хронологическом порядке: «Шерлок Холмс» Гая Ричи (2009, США); «Шерлок» Марка Гэтисса (2011-2016, Великобритания) и «Шерлок Холмс» Андрея Кавуна (2013, Россия). Критерий анализа полученных ответов - 10-ти балльная уровневая система восприятия репрезентации героя в каждой из экранизаций: 1-3 балла - низкий уровень, 4-6 - средний уровень, 7-10 - высокий уровень. Все полученные результаты были суммированы, вычислен средний балл по каждой из анкет, а затем - средний балл по каждой из оцениваемых респондентами экранизаций. Такая система позволила перевести качественные результаты (ответы респондентов) в количественные данные, обработанные затем с

\footnotetext{
${ }^{6}$ Сидней Пэджет создал канонический образ Шерлока и Ватсона на страницах "Strand Magazine" в 1891 г. в иллюстрациях к рассказу “Скандал в Богемии». Именно на этот образ ориентировались создатели многих фильмов и сериалов о знаменитом сыщике: по этим рисункам Игорь Масленников подбирал актеров для своего сериала «Приключения Шерлока Холмса и доктора Ватсона» (1979-1986).
} 
помощью специального программного обеспечения Neural Designer, применяемого для расширенной статистической аналитики.

Предложенная для мини-опроса анкета включала следующие вопросы:

1. Оцените, насколько образ Шерлока Холмса соответствует идее высшей справедливости?

2. Оцените, насколько внешность героя отражает его характер?

3. Оцените, насколько выражена гениальность героя в данной экранизации?

4. Оцените, насколько выражена социопатия героя в данной экранизации?

5. Оцените, насколько опасен может быть такой герой?

6. Оцените, насколько может быть надежен такой герой, как выразитель идеи справедливости?

Представленные вопросы позволили выявить отношение зрителей к герою, а также выяснить основную тенденцию в кинематографических репрезентациях Шерлока Холмса на современном этапе развития этого образа.

В проведенном нами мини-опросе приняли участие 150 респондентов. Опрос проведен на двух языках (русском и английском), что позволило расширить аудиторию респондентов. Исследование проведено в период с 1 по 20 мая 2021.

\section{РЕЗУЛЬТАТЫ}

Проведенное исследование дало следующие результаты: по экранизации Гая Ричи 90\% респондентов оценили героя как ненадежного, слишком эмоционального, неуравновешенного человека, который не в состоянии без своего спутника сыграть значимую роль в достижении высшей справедливости. Среди ответов респондентов встречались, например, следующие замечания: «он постоянно пьяный, мне это не нравится, как можно расследовать что-то, если он просто не стоит на ногах», «мне кажется, если бы не Ватсон, такого Шерлока несколько раз убили бы в Лондоне даже среди белого дня»; «Дауни Младший имеет свойство быть героем, но он не приблизился к Холмсу ни на шаг» и т.п. Статические данные результатов опроса представлены на Рис. $6^{7}$.

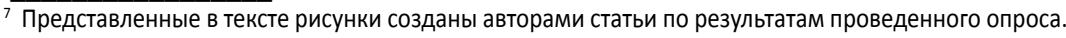




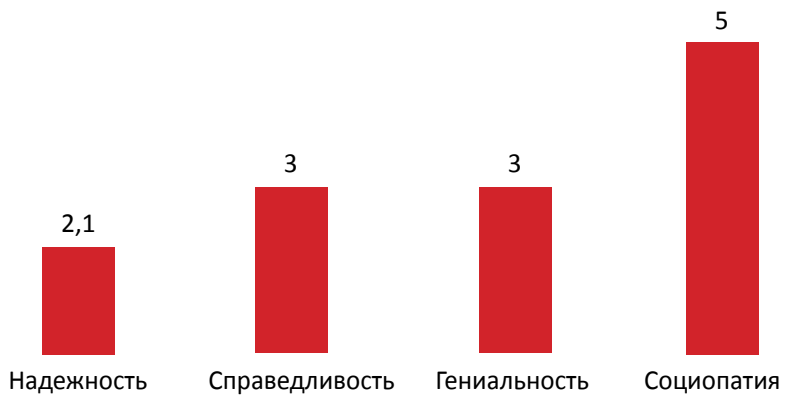

Рис. 6. Репрезентация героя в экранизации Гая Ричи

Как можно видеть по данным, приведенным на Рис. 6, в репрезентации героя в экранизации Гая Ричи социопатия выходит на первый план, справедливость, надежность и гениальность оценены зрителем на низком уровне.

По экранизации Марка Гэтисса были получены следующие результаты: 75\% респондентов оценили Шерлока как социопата, 15\% как гения и воплощение высшей справедливости. При этом в ответах респондентов встречались следующие высказывания: «мне этот Шерлок нравится, он какой-то необычный», «он больше похож на гения, чем на пьяницу, как было у Гая Ричи», «Камбербэтч не подходит на роль классического Холмса, но то, что хотел режиссер, актер выразил вполне». В репрезентации героя сыграли свою роль работа камеры, саундтрэк, высокое качество работы сценаристов: «блестящий сценарий, без него Холмс Камбербэтча был бы очень скучным», "работа оператора просто на высоте, камера спасла Камбербэтча от провала». Интересно, что респонденты особо отметили технические способы репрезентации героя. При этом также $85 \%$ обратили внимание на то, что «Холмс существует только благодаря Ватсону", "персонаж больше нравится, чем Холмс», "Ватсон более натуральный получился, чем Шерлок». Вторая анализируемая нами экранизация, таким образом, позволила выявить роль технических средств в репрезентации героя, а также смещение акцента с протагониста на спутника героя.

Результаты опроса по второй экранизации представлены на Рис. 7. 


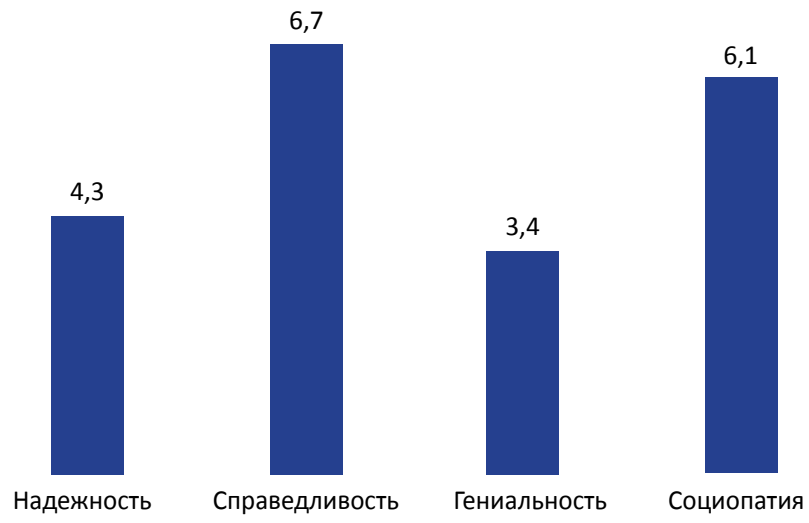

Рис. 7. Репрезентация героя в экранизации Марка Гэтисса

Как видно по данным, представленным на Рис. 7, основными характеристиками репрезентации героя в экранизации Марка Гэтисса стали социопатия и идея справедливости, при этом надежность героя была оценена на среднем уровне, а его гениальность заслужила низкую оценку.

Об экранизации Андрея Кавуна (Рис. 8) были получены следующие данные: 89\% респондентов оценили Холмса как ненадежного, неуравновешенного, невротика, фактически социопата, практически без признаков гениальности. При этом были высказаны следующие мнения: «он бегает как ужаленный осой весь фильм, у него руки трясутся, он весь дерганный и неуверенный в себе», «как человек, который не в состоянии справиться с собственными эмоциями, может что-то расследовать», «Холмс выглядит как психически больной человек», «он все время пыхтит и произносит слова сквозь зубы, он странный». 


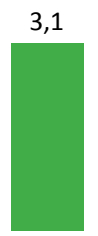

3,2
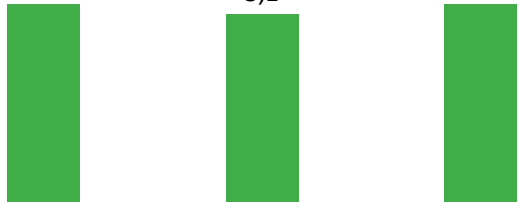

Надежность

Справедливость

Гениальность

Социопатия

Рис. 8. Репрезентация героя в экранизации Андрея Кавуна

Сводная диаграмма данных о трех экранизациях демонстрирует увеличение социопатии в репрезентации героя (Рис. 9):

\section{Сводные данные о трех экранизациях}

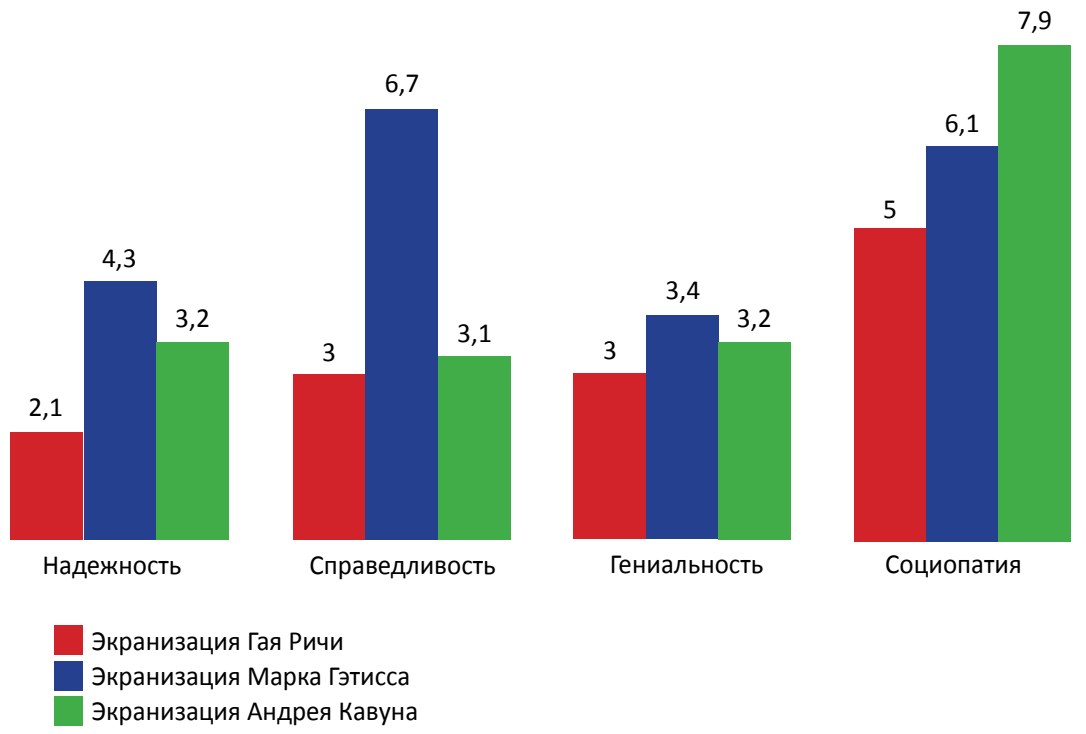

Рис. 9. Сводные данные о трех экранизациях 
Отметим, что в этой экранизации образ спутника героя вызвал полную симпатию как антипод представленному Холмсу: «Ватсон всегда собран, умен, справедлив и человечен, он лучше, чем Холмс», "без Ватсона такой Холмс вообще нереальное явление, он бы от истерик своих умер раньше времени». Такие мнения говорят о том, что репрезентация героя через персонаж-спутник привела к прямо обратному эффекту: зрители не воспринимают героя как главного, а второстепенный персонаж занимает центральное место.

\section{ВЫвОДЫ}

Проведенное нами исследование репрезентации героя на примерах трех экранизаций произведений о Шерлоке Холмсе позволяет сделать следующие выводы:

1. Частные выводы: в современных экранизациях социопатия и неврастения преобладают над гениальностью, что с одной стороны, дает кинематографистам возможность расширить статические характеристики образа, но с другой - сужает поле репрезентации самой социопатией, не позволяя ему реализовать социальную функцию идей высшей справедливости, торжества научного мышления и рационализма, важных составляющих литературного мифа Шерлока Холмса. Во всех трех экранизациях героем подчеркнуто движет не идея торжества правосудия (собственно, и канонический Шерлок расследует очередное дело ради интеллектуального вызова), а личностные мотивы, в основном - любовные (особенно ярко выраженные в экранизации А. Кавуна в истории трагической любви Холмса и Ирен Адлер, намеченной лишь пунктиром в рассказе А. Конан Дойла «Скандал в Богемии»), эмоциональные и сентиментальные, что приводит к определенному искажению архетипа. В свою очередь, такие репрезентации воспринимаются зрителем (часто не знакомым с литературным источником) не столько как очередная экранная версия произведений А. Конан Дойла, но и как самостоятельное произведение с оригинальным сюжетом. Ограниченное взаимодействие героя-интроверта с обществом, в свою очередь, приводит кинематографистов к необходимости создания образа более сильного посредника между героем и обществом, в которого фактически превратился Ватсон во всех трех экранизациях. Поэтому верный аколит Холмса вызывает большую симпатию зрителей, чем главный герой-социопат. Более того, в сериале А. Кавуна (Рис.10) Ватсон фактически становится своеобразным новым Пигмалио- 
ном: созданный Ватсоном литературный образ его друга в финале сериала обретает канонические черты Холмса с рисунков С. Пэджета. И сам Холмс повинуется творческой воле своего создателя.

2. Общие выводы: в современных экранизациях выявлена попытка радикально переосмыслить архетип, в определенном смысле повлиявший на несколько поколений (Холмс не только как воплощение высшей справедливости, но и как гармонизирующее начало в неовикторианском дискурсе), путем абсурдизации образа героя. Предпринимаются в том числе высмеивание и примитивизация героя: например, в получившей крайне негативную реакцию зрителей американской пародийной комедии Уилла Феррела «Холмс и Ватсон» (2018) или же мокбастере Рэйчел Ли Голденберг "Sir Arthur Conan Doyle's Sherlock Holmes» (2010). Такие экранизации считаются не только неудачными, но даже вызывают недовольство британского королевского двора [11, с. 47]. Более того, сама попытка высмеивания архетипического героя и разрушения мифа Холмса приводит к карьерным неудачам актеров и к зрительскому забвению таких экранизаций. Шерлок Холмс до сих пор вдохновляет кинематографистов и как социальный феномен, и как вечный образ, литературный миф, даже в своих статических характеристиках открытый для импровизаций. Здесь, на наш взгляд, два пути: быть осторожными и корректными в отношении стиля, сути первоисточника, и литературного и кинематографического мифа, либо создавать совершенно новый стиль повествования и новый образ, как это сделали и Гай Ричи, снявший оба фильма о Холмсе в стилистике стимпанка, и Андрей Кавун, и Нурбек Эген. Возможно при этом, что идея высшей справедливости, важная составляющая литературного мифа и экранного образа Холмса как супергероя, но, как замечает Никита Карцев, без костюма и маски Бэтмена или доспехов Железного человека [25], не должна, на наш взгляд, быть пошлой, глупой или смешной. Это одна из общепринятых социальных фундаментальных ценностей, а Шерлок Холмс воплощает эту справедливость для нескольких поколений читателей и зрителей. К сожалению, современные экранизации становятся, на наш взгляд, не только далеко отходящими и от литературного источника (в цитированной рецензии на фильм Гая Ричи А. Анастасьев пишет, что главных героев можно было бы назвать Тарапунька и Штепсель), и от признанных классическими экранизациями, но все более и более спорными. Психически нездоровый Шерлок Холмс («Элементарно» Майкла Куэста), экзальтированный, почти истеричный неврастеник («Шерлок Холмс» Ан- 
дрея Кавуна) априори не могут являть ни высшую справедливость, ни рациональное гармонизирующее начало, в связи с чем происходит выпадение экранного образа из архетипа: все странные Шерлоки («Тот самый, но другой» - слоган сериала Андрея Кавуна) не воспринимаются как герои, а только как череда примитивизированных версий (Рис. 10).

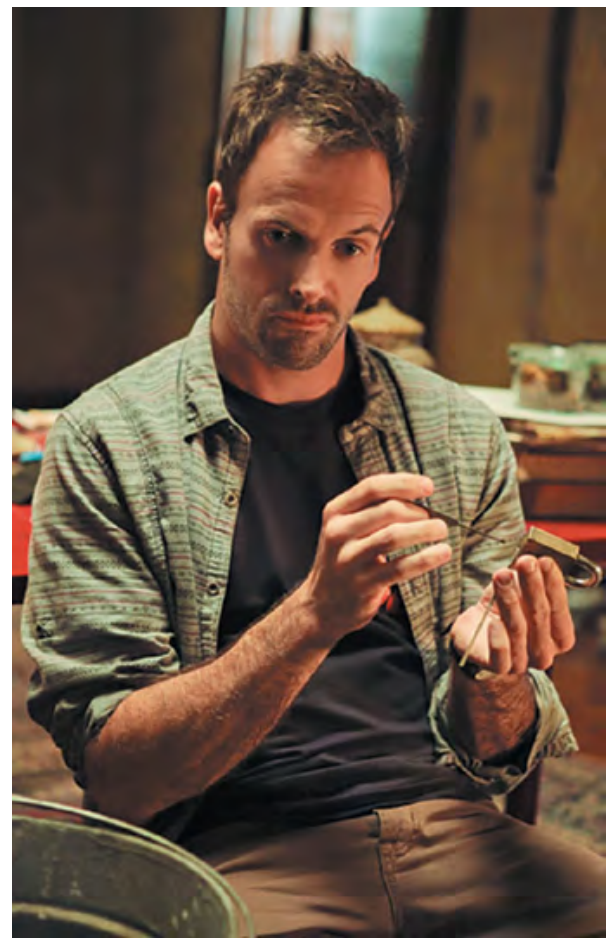

Рис. 10. Шерлок Холмс в исполнении американского актера Джонни Ли Миллера.

Кадр из детективного сериала «Элементарно» (англ. Elementary), основанного на персонажах книг Артура Конан Дойла о Шерлоке Холмсе, действие происходит в наши дни.

Премьера состоялась на телеканале CBS 27 сентября 2012 года ${ }^{8}$

Перспективным представляется дальнейшее исследование динамики социальных характеристик экранного героя-социопата такого масштаба как Шерлок Холмс. Анализ интерпретаций и самого литературного

\footnotetext{
${ }^{8}$ Источник изображения см.: URL: https://www.kino-teatr.ru/kino/acter/m/euro/59398/foto/ $\mathrm{m} 100008 / 356360 /(08.07 .2021)$.
} 
мифа, и его экранного воплощения представляют собой несомненный научный интерес, поскольку отражают состояние самого общества, трансформаций его моральных, этических и эстетических ценностей.

\section{ЛИТЕРАТУРА}

1. Экранная культура. Теоретические проблемы: сборник статей / отв. ред. К.Э. Разлогов. СПб.: Дмитрий Буланин, 2012. 752 с.

2. Ющенко О.И., Гамалеева Ю.А. Художественный кинематограф и его роль в формировании образа национального героя на примере личности Уинстона Черчилля // История и современное мировоззрение. 2020. Т. 2. № 3. С. 118-123. URL: https://urvak.ru/articles/istor-4577-vypusk-3-khudozhestvennyy-kinematograf-/.

3. Эйзенштейн С.М. О чистоте киноязыка // Эйзенштейн С.М. Избранные произведения: в 6 т. М.: Искусство, 1964. Т. 2. С. 81-92.

4. Работа оператора // Кулешов Л.В. Искусство кино (мой опыт). Ленинград: Теа-кино-печать, 1929. Гл. IV. С. 75-95.

5. Янковский А.Н. Игра «квест» как синтез литературных и кинематографических традиций // Культура и искусство. 2018. № 9. С. 50-58. DOI: https://doi. org/10.7256/2454-0625.2018.9.27465.

6. Колотаев В.А., Марков А.В. Проблематизация феномена киноидентичности в исследованиях киноискусства // Артикульт. 2019. № 3. С. 130-145. https://doi. org/10.28995/2227-6165-2019-3-130-145.

7. Шапинская Е.Н. Экзистенциальный другой: рефлексии и репрезентации // Культура культуры. 2019. № 4. С. 1-16.

8. Polasek A.D. The evolution of Sherlock Holmes: adapting character across time and text. De Montfort University, 2014. 316 p.

9. Naidu S. Sherlock Holmes in Context. London: Palgrave MacMillan UK, 2020. $137 \mathrm{p}$.

10. Buchmann A. The mediatization of Sherlock Holmes // The Routledge Companion to Media and Tourism. Milton, UK: Routledge, 2020. P. 326-336.

11. Benette L., Hwang D. The Adventures of Sherlock Holmes. London: CoPublished with Ws Education (Children's), 2021. $127 \mathrm{p}$.

12. Анастасьев А. Исчезновение Шерлока Холмса. «Шерлок Холмс», режиссер Гай Ричи // Искусство кино. 2010. № 1. С. 54-60. URL: https://old.kinoart.ru/ archive/2010/01/n1-article11 (дата обращения: 03.07.2021).

13. McCaw N. Sherlock Holmes and a Politics of Adaptation // Sherlock Holmes and Conan Doyle / ed. by S. Vanacker, C. Wynne. Second Edition. London: Palgrave Macmillan UK, 2020. P. 36-48.

14. Тынянов Ю.Н. Об основах кино // Поэтика кино / под ред. Б.М. Эйхенбаума. М.; Л.: Кинопечать, 1927. С. 55-85. 
15. Шкловский В.Б. Революция Медиа // Шкловский В.Б. Собрание сочинений. Т. 1: Революция / сост., вступ. ст. И. Калинина. М.: Новое литературное обозрение, 2018. С. 709-871.

16. Эйзенштейн С.М. За кадром // Эйзенштейн С.М. Избранные произведения: в 6 т. М.: Искусство, 1964. Т. 2. С. 283-297.

17. О сценарии // Кулешов Л.В. Искусство кино (мой опыт). Л.: Теа-кино-печать, 1929. Гл. V. С. 98-112.

18. Сюжет в кино // Лотман Ю.М. Семиотика кино и проблемы киноэстетики. Таллин: ЭэстиРаамат, 1973. Гл. 9. С. 38-46.

19. Осьмухина О.Ю. Образ героя-детектива: специфика интерпретации литературой и современным кинематографом // Филологические науки. Вопросы теории и практики. 2019. Т. 12. № 2. С. 389-393. https://doi.org/10.30853/ filnauki.2019.2.83

20. Савельева Т.В. Медийный образ ученого - фольклориста, этнографа, антрополога, лингвиста (на примере российских и зарубежных кинофильмов) // Знак: проблемное поле медиаобразования. 2018. № 2 (28). С. 216-221.

21. Шапинская Е.Н. Монстр как культурный герой: репрезентация монструозности в массовой культуре (начало) // Культура культуры. 2019. № 2. С. 1-13.

22. Кракауэр 3. Природа фильма: Реабилитация физической реальности. М.: Искусство, 1974. 442 с.

23. McFarlane B. Novel to Film: An Introduction to the Theory of Adaptation. Oxford: Clarendon Press, 1996. 296 p.

24. Егиазарова И. Рецензия на сериал «Шерлок в России»: парадный выход Богомолова, постельная сцена с Матвеевым и порция кулинарного юмора // Вокруг TB: сайт. 2020. 22 октября. URL: https://www.vokrug.tv/article/show/16033034261/ (дата обращения: 03.07.2021).

25. Карцев Н. Трубка, шляпа и Ватсон - вот мои документы // GQ. 2013. 19 ноября. URL: https://www.gq.ru/entertainment/trubka-shlyapa-i-vatson-vot-moidokumenty (дата обращения: 24.06.2021). 
СВЕДЕНИЯ ОБ АВТОРАХ

\section{БЕЛЛА АХМЕДОВНА БУЛГАРОВА}

кандидат филологических наук, доцент кафедры массовых коммуникаций, Российский университет дружбы народов, 117198, Москва, ул. Миклухо-Маклая, 10 к. 2

ResearcherID: G-3631-2016

ORCID: 0000-0001-6005-2505

e-mail: bulgarova-ba@rudn.ru

\section{АЛЕКСЕЙ ЮРЬЕВИЧ ОВЧАРЕНКО}

доктор филологических наук, доцент кафедры русского языка, заведующий кафедрой лингводидактики и тестологии, Российский университет дружбы народов, 117198, Москва, ул. Миклухо-Маклая, 6

ResearcherID: Z-3696-2019

ORCID: 0000-0002-8544-5812

e-mail: ovcharenko_ayu@pfur.ru

\section{ВИКТОР ВЛАДИМИРОВИЧ БАРАБАШ}

доктор филологических наук, профессор кафедры массовых коммуникаций, декан филологического факультета, Российский университет дружбы народов, 117198, Москва, ул. Миклухо-Маклая, 10 к. 2

ResearcherID: P-6349-2017

ORCID: 0000-0002-8909-2145

e-mail: barabash-vv@rudn.ru

\section{ЮЛИЯ АЛЕКСАНДРОВНА ВОРОПАЕВА}

кандидат педагогических наук, доцент кафедры русского языка, Российский университет дружбы народов, 117198, Москва, ул. Миклухо-Маклая, 6

ResearcherID: AAN-5202-2020

ORCID: 0000-0002-5425-3359

e-mail: voropaeva_yua@pfur.ru 